\title{
Review \\ Developments on Perovskite Solar Cells (PSCs): A Critical Review
}

\author{
Lehlohonolo P. Lekesi ${ }^{1}$, Lehlohonolo F. Koao ${ }^{2}$, Setumo V. Motloung ${ }^{2,3, *}$, Tshwafo E. Motaung ${ }^{2,4}$ \\ and Thembinkosi Malevu ${ }^{4, *}$
}

1 Westville Campus, School of Chemistry and Physics, University of KwaZulu-Natal, Private Bag X54001, Durban 4000, South Africa; hlonnylekesi@gmail.com

2 Department of Chemistry/Physics, Sefako Makgatho Health Science University, P.O. Box 94, Medunsa 0204, South Africa; koaoLF@ufs.ac.za (L.F.K.); motaungte@live.com (T.E.M.)

3 Department of Chemical and Physical Sciences, Walter Sisulu University, Private Bag X1, Mthatha 5148, South Africa

4 Department of Chemistry, School of Science, College of Science Engineering and Technology, University of South Africa, Preller Street, Muckleneuk Ridge, P.O. Box 392, Unisa 0003, South Africa

* Correspondence: cchataa@gmail.com (S.V.M.); thembinkosi.malevu@smu.ac.za (T.M.)

check for updates

Citation: Lekesi, L.P.; Koao, L.F.; Motloung, S.V.; Motaung, T.E.; Malevu, T. Developments on Perovskite Solar Cells (PSCs): A Critical Review. Appl. Sci. 2022, 12, 672. https://doi.org/10.3390/ app12020672

Academic Editor: Takayoshi Kobayashi

Received: 29 November 2021 Accepted: 21 December 2021 Published: 11 January 2022

Publisher's Note: MDPI stays neutral with regard to jurisdictional claims in published maps and institutional affiliations.

Copyright: (C) 2022 by the authors. Licensee MDPI, Basel, Switzerland. This article is an open access article distributed under the terms and conditions of the Creative Commons Attribution (CC BY) license (https:// creativecommons.org/licenses/by/ $4.0 /)$.

\begin{abstract}
This review provides detailed information on perovskite solar cell device background and monitors stepwise scientific efforts applied to improve device performance with time. The work reviews previous studies and the latest developments in the perovskite crystal structure, electronic structure, device architecture, fabrication methods, and challenges. Advantages, such as easy bandgap tunability, low charge recombination rates, and low fabrication cost, are among the topics discussed. Some of the most important elements highlighted in this review are concerns regarding commercialization and prototyping. Perovskite solar cells are generally still lab-based devices suffering from drawbacks such as device intrinsic and extrinsic instabilities and rising environmental concerns due to the use of the toxic inorganic lead $(\mathrm{Pb})$ element in the perovskite $\left(\mathrm{ABX}_{3}\right)$ light-active material. Some interesting recommendations and possible future perspectives are well articulated.
\end{abstract}

Keywords: perovskite solar cells; chemical stability; material toxicity; device structure; efficiency

\section{Introduction}

The world is in great demand for energy in the form of electricity, as electricity contributes to economic growth [1]. The world's dependence on burning fossil fuel for this purpose is consequential, as fossil fuels are slowly becoming depleted and emit harmful toxins into the atmosphere [2,3]. Resorting to renewable energy, such as solar energy, offers the advantage to counteract both issues of energy sustainability and the negative impact on the environment. Therefore, resources that generate electrons for the above purpose are promising alternative sources of energy. The emerging perovskite solar cells (PSCs) are photovoltaic (PV) devices able to convert the abundant sunlight radiation into electricity. The cell operates similar to a traditional p-n junction solar cell, with the perovskite material producing electrons and holes for electricity generation. This type of PV solar cell is novel and has gained attention recently mainly due to its high efficiency, low production cost, and easy fabrication [4-8]. PSCs offer a shift from overusing Earth's non-renewable resources to harvesting the infinite sunlight radiation.

\section{Perovskite Solar Cells (PSCs)}

PSCs belong to the 3rd generation of photovoltaic cells and their device structure is integrated from the second-generation dye-sensitized solar cells (DSSCs) configuration $[9,10]$ The low absorption coefficient of organic sensitizers in DSSCs limits the light-harvesting 
ability of the cell; hence, DSSCs are low-efficiency cells. Kojima (2009) studied the PV effect in a photoelectrochemical (PEC) dye-sensitized cell by replacing the dye organic molecules with organic-inorganic halide perovskite molecules such as $\mathrm{CH}_{3} \mathrm{NH}_{3} \mathrm{PbBr}_{3}\left(\mathrm{MAPbBr}_{3}\right)$ and $\mathrm{CH}_{3} \mathrm{NH}_{3} \mathrm{PbI}_{3}\left(\mathrm{MAPbI}_{3}\right)$ and registered power conversion efficiencies (PCE) of $3.1 \%$ and $3.8 \%$, respectively [5]. Although perovskites show good PV properties, including optical, excitonic, and electrical conductivity, the above unfavorable low efficiencies were attributed to the dissolution of the perovskite material by the liquid electrolyte [11].

Attempts have been made to stabilize the crystalline perovskite material in DSSCs. Lee (2009) reported an increase in PCE of lead halide perovskites, while many researchers focused on quantum dot sensitized solar cells (QDSSCs) using inorganic metal chalcogenides sensitizers such as $\mathrm{PbS}, \mathrm{CdSe}$, and $\mathrm{CdS}$ as light-absorbing materials, exhibiting intense bandgap light absorption [12-14]. However, these quantum dot cells suffered from low efficiencies between 1.2 and $6.4 \%$ due to charge recombinations at the interface and chemical instability. To overcome these challenges, the $\mathrm{MAPbI}_{3}$ perovskite materials were explored as quantum dots in PECs and an increase to 6.5\% in PCE in PSCs was achieved [15]. To further increase efficiencies, Fujishima (2005) proposed the use of hole-transporting materials (HTMs) in DSSC s to eliminate the drawbacks caused by liquid electrolytes in PECs. In a later study, Lee (2012) developed a 10\% PCE solid-state PSC device using Spiro-MeOTAD HTM in a perovskite-sensitized solar cell device [16,17].

Device fabrication of a solid-state PSC consists of a perovskite precursor solution deposition between spaces of mesoporous titanium dioxide $\left(\mathrm{TiO}_{2}\right)$, thin-film on a transparent conductive oxide (TCO) substrate, forming a $\mathrm{ABX}_{3}$ perovskite layer by an ordered ion agglomeration process, then followed by Spiro-MeOTAD (HTM) deposition, resulting in devices reaching efficiencies of up to $9.7 \%$ (see Figure 1a,b). The use of mixed-halide perovskite crystals such as $\mathrm{MAPbI}_{3-\mathrm{x}} \mathrm{Cl}_{\mathrm{x}}$ helps avoid the dissolution of the perovskite material by the Spiro-MeOTAD-dissolving solvents during the deposition [18,19]. It is further found that the use of insulating mesoporous aluminium oxide $\left(\mathrm{Al}_{2} \mathrm{O}_{3}\right)$ instead of mesoporous $\mathrm{TiO}_{2}$ results in better PCE. The $\mathrm{Al}_{2} \mathrm{O}_{3}$ appears to act as a structural scaffold in the perovskite material, demonstrating that the $\mathrm{ABX}_{3}$ perovskite crystal structure contributes to the electron transport, hence, demonstrating devices with high charge collection (see Figure 1c $[17,20,21]$. The reduction in device thickness is shown in Figure 1d-g, sensitized cell structure (d) $\rightarrow$ mesoporous structure (e) $\rightarrow$ meso-superstructure (f) and, lastly, $\rightarrow$ planar cell structure $(\mathrm{g})$ has also contributed towards achieving highly efficient photon-to-electron thin PVs.

The developments in designing the $\mathrm{ABX}_{3}$ crystal structure and advances in device structure is of topical research, attracting the interest of many chemists and physicists across the world. This has attributed a rapid increase in PSC efficiencies to $25.5 \%$, approaching the $27.6 \%$ efficiency for commercially available single crystalline silicon solar cells [22-24]. However, recording high efficiencies, PSCs are still lab-based devices and have not reached commercialization due to the device instabilities and the current use of the toxic inorganic lead $(\mathrm{Pb})$ element. Factors affecting the PSC's stability include environmental variations such as oxygen, moisture, temperature, and UV radiation [25-27]. Thus, the major challenge in manufacturing is achieving a device with high performance, is environmentally friendly, and has a life span of 25 years.

The perovskite active layer, together with the counter electron and hole transporting layer (ETL and HTL), are key components in the solar cell device [28]. Therefore, this work provides comprehensive literature on perovskite crystal structure modelling, perovskite $\left(\mathrm{ABX}_{3}\right)$ compositional engineering, and maps out the road towards establishing the perfect required ETL/perovskite and perovskite/HTM intermediate contacts [29,30]. Interesting recommendations and possible future perspectives are also outlined. 


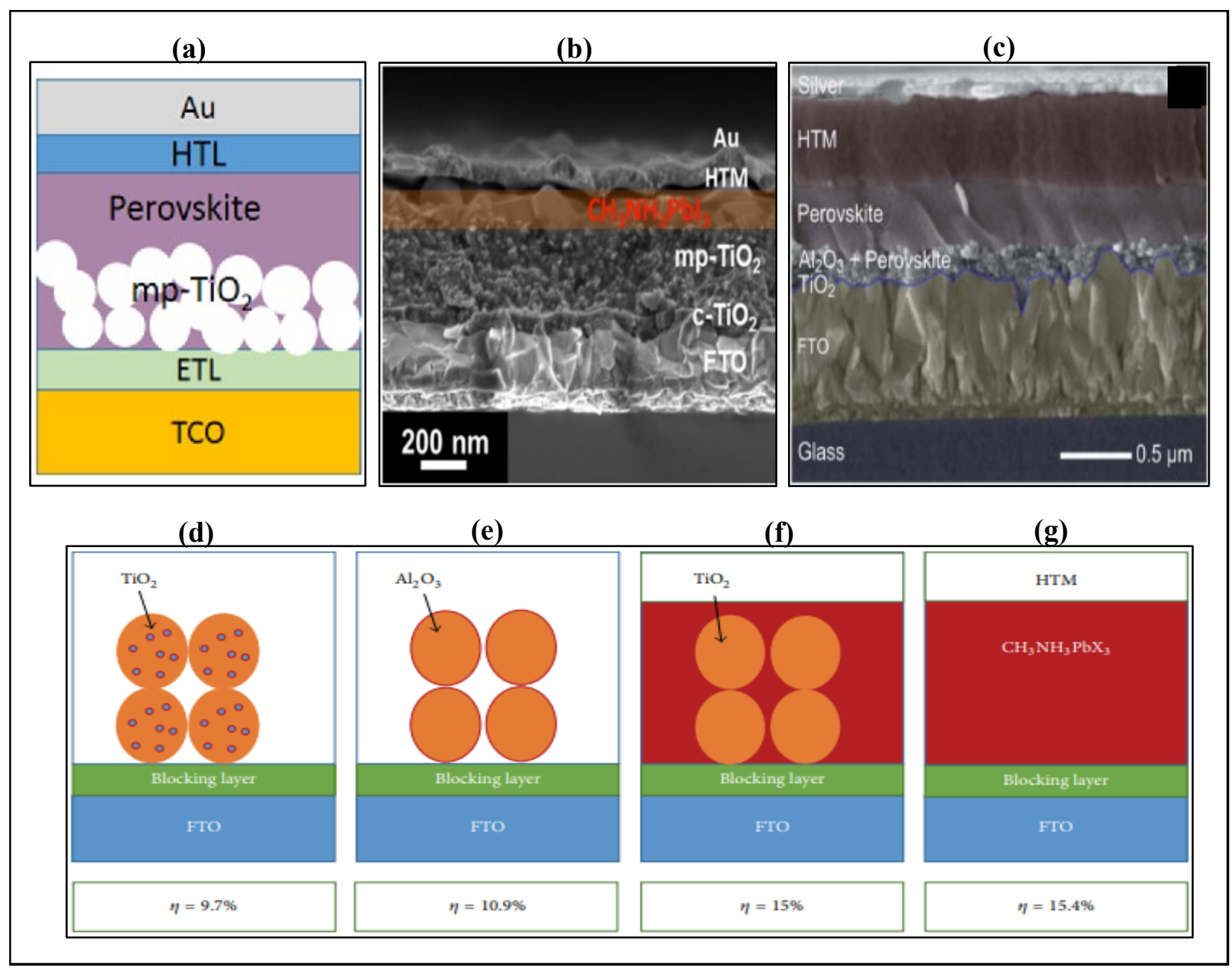

Figure 1. (a) Schematic representation of a solid-state perovskite sensitized device structure. SEM cross-sectional images of PSCs based on mesoporous (b) $\mathrm{TiO}_{2}$ and (c) $\mathrm{Al}_{2} \mathrm{O}_{3}$. Progress in PSC efficiency with the cell structure: (d) sensitized PSC $\eta=9.7 \%$, (e) mesoporous PSC $\eta=10.9 \%$, (f) mesosuperstructure PSC $\eta=15 \%$, and (g) planar heterojunction thin-film PSC $\eta=15.4 \%[9,10,17,21]$.

\section{Modelling the Perovskite Crystal Structure}

In perovskite solar cells $\mathrm{MAPbI}_{3}, \mathrm{FAPbBr}_{3}$, and $\mathrm{CsPbCl}_{3}$ are standard $\mathrm{ABX}_{3}$ lightabsorbing materials [31]. The arrangement of ions in the perovskite crystal structure varies in space around a unit cell depending on temperature $(\mathrm{T})$, pressure $(\mathrm{P})$, and tolerance factor (t). The perovskite crystal structure ranges from orthorhombic, tetragonal, and cubic in order of increasing crystal perfection, respectively [32]. The tolerance factor $(t)$ predicts stability in perovskite crystal systems. In a perfect perovskite cubic structure, the (t) factor equals 1.0, whereas in a non-ideal case, the cubic structure is within 0.8 to $1.0(\mathrm{t})$ factor. Less ordered perovskite crystal structures, such as orthorhombic and tetragonal, are obtained at low $(\mathrm{t})$ factor $[19,26]$. $\mathrm{FA}^{+}$containing perovskite materials have a high $(\mathrm{t})$ factor. Alloys of $\mathrm{MA}^{+}$and $\mathrm{Cs}^{+}$multi-cation perovskites result in materials with properties comparable to $\mathrm{FA}^{+}$alone. This concludes that $\mathrm{FA}^{+}$containing perovskites are more stable than the individual $\mathrm{MA}^{+}$and $\mathrm{Cs}^{+}$containing perovskite materials [33]. Figure 2 shows $\mathrm{MAPbI}_{3}$ phase transitions with an increase in temperature. The (t) factor equation is given as follows.

$$
\mathrm{t}=\frac{\mathrm{r}_{\mathrm{A}}+\mathrm{r}_{\mathrm{X}}}{\sqrt{2} \times\left(\mathrm{r}_{\mathrm{B}}-\mathrm{r}_{\mathrm{X}}\right)}
$$

where $r_{A}, r_{B}$, and $r_{X}$ represent the ionic radii for the organic cation $A$, inorganic cation $B$, and the halide anion $X$, respectively, from the $\mathrm{ABX}_{3}$ perovskite crystal structure [31]. 

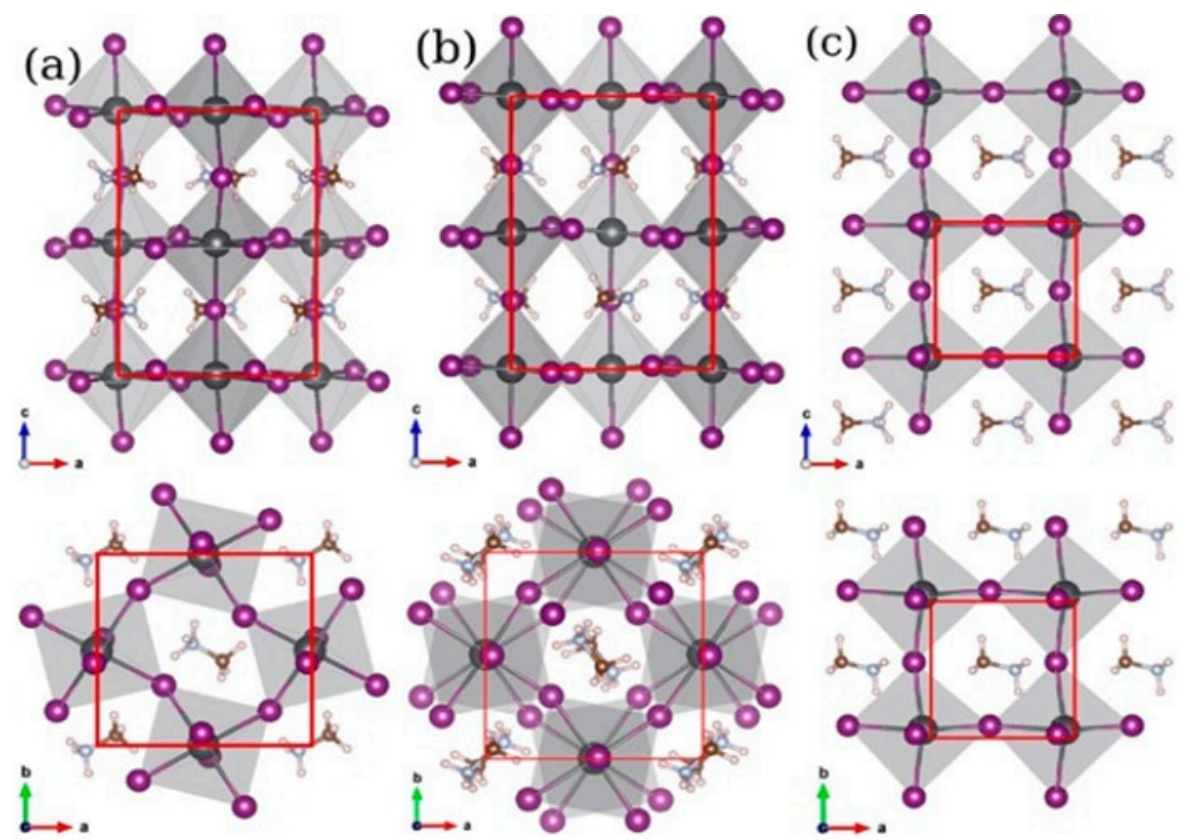

Figure 2. $\mathrm{MAPbI}_{3}$ phase transitions arranged in order of increasing temperature (a) orthorhombic, (b) tetragonal, and (c) cubic perovskite phases [34].

\section{Modelling the Perovskite Electronic Structure}

Methylammonium lead iodide $\left(\mathrm{MAPbI}_{3}\right)$ is the simplest and well-studied perovskite absorber compound. Its crystal structure consists of an organic $\mathrm{MA}^{+}$molecule surrounded by three-dimensional inorganic $\mathrm{Pb}-\mathrm{I}$ molecules. Figure $3 \mathrm{a}-\mathrm{f}$ demonstrate the effect of $\mathrm{MA}^{+}$ $-001,-110$, and -111 ionic orientations in the bandgap structure of cubic and tetragonal $\mathrm{MAPbI}_{3}$, determined from Perdew-Burker-Ernzerhof function for solids. It is observed that the conduction (CB) and valence (VB) band of the $\mathrm{MAPbI}_{3}$ electronic structure vary with $\mathrm{MA}^{+}$orientation; however, the overall electronic bandgap remains the same throughout 001, 110-, and 111-MA' ionic orientations. This, therefore, suggests that the $\mathrm{MAPbI}_{3}$ bandgap depends on the three-dimensional $\mathrm{Pb}$-I system surrounding the $\mathrm{MA}^{+}$ion, and not on the $\mathrm{MA}^{+}$ion [33,35-37]. In additional studies on the $\mathrm{MAPbI}_{3}$ electronic structure, Yin (2014) studies on the density of states (DOSs) emphasizes more on the above suggestion. Figure $3 g$ illustrates $\mathrm{MAPbI}_{3}$ total and partial DOSs. It is observed from the DOS positions of lead $(\mathrm{Pb})$ and iodide (I) p-orbitals in Figure $3 g$ occupy the $\mathrm{CB}$ and VB, respectively, indicating that $\mathrm{MAPbI}_{3}$ optical transitions rely on $\mathrm{Pb}$ and I p-p transitions (see Figure $3 g$ ) $[35,38]$. 
Cubic MAPbI

band structure
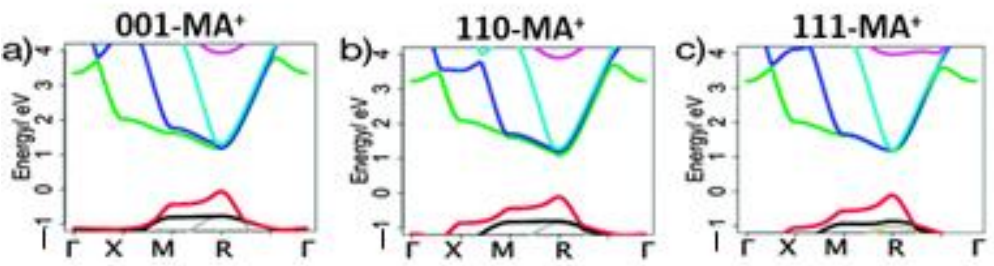

Tetragonal MAPbI

band structure
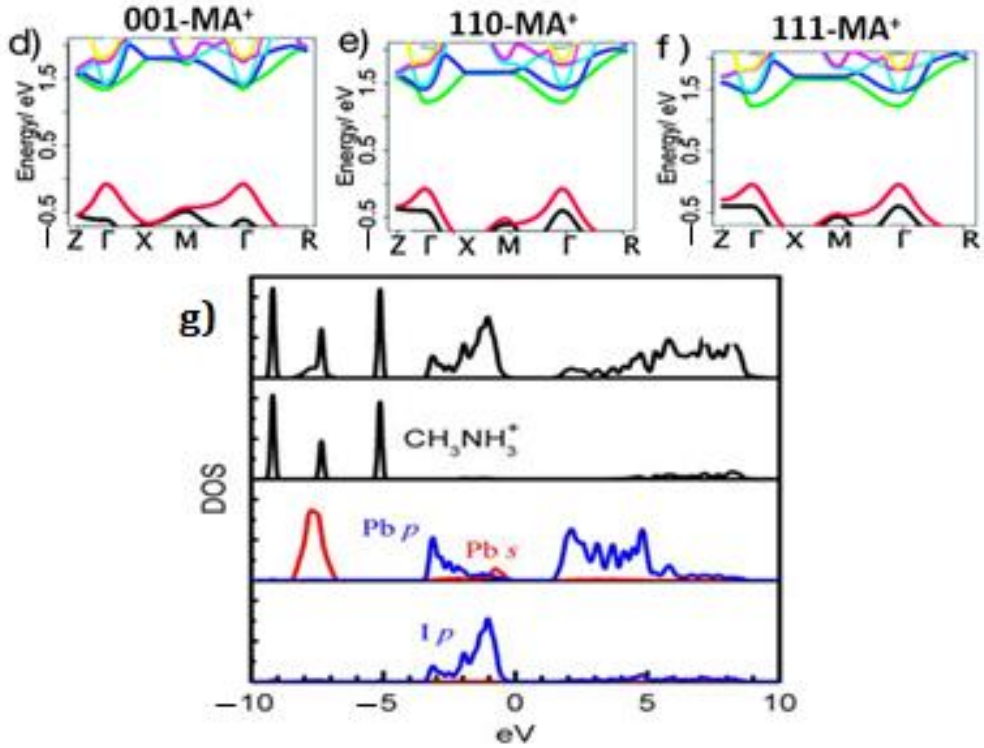

Figure 3. Band-gap structure of a cubic (a-c) and tetragonal (d-f) $\mathrm{MAPbI}_{3}$ crystal structure. Total and partial density of states of $\mathrm{MAPbI}_{3}$ and ions $(\mathbf{g})[35,36]$.

\section{Perovskite Solar Cell Device Architecture}

PSCs were first reported by Kojima (2009), whereby the perovskite $\mathrm{ABX}_{3}$ organicinorganic lead halide material was used as a light absorber in sensitized solar cells. In this study, the perovskite device structure preserved the same cell structure as DSSCs. Hence, it was assumed that PSCs operate similar to DSSCs. However, as knowledge developed in this field, it was found that the fundamental basis of operation in PSCs was distinctive from DSSCs [15,37]. In a PSC device, the perovskite material $\left(\mathrm{ABX}_{3}\right)$ is deposited onto a conductive glass substrate bearing an n-type (compact or mesoporous) electron transport material (ETM), which is followed by the deposition of a p-type hole transport material (HTM). When light is absorbed by the perovskite material, electrons are excited to the LUMO, leaving behind holes in the perovskite HOMO, generating excitons that diffuse within the perovskite layer towards the opposite ETM and HTM contacts. At the interface with the perovskite material, the ETM and HTM selectively transport charge carriers. Electrons travel from the anode electrode to the external circuit, generating electricity across an electrical load. The perovskite absorber regenerates as electrons recombine with holes at the cathode electrode (e.g., $\mathrm{Au}, \mathrm{Ag}, \mathrm{Pt}$, and $\mathrm{Al}$ ), minimizing charge imbalance at opposite electrodes [39].

A conventional PSC has a device architecture similar to a p-n junction solar cell with the perovskite intrinsic (i) absorber sandwiched between n-type and p-type semiconducting materials, as illustrated in Figure 4a; this device architecture is referred to as the mesoscopic(n-i-p) device architecture. The realization that the perovskite material can, on its own, facilitate charge transportation and further the rearrangement of the device architecture 
has contributed significantly towards improving the device performance and stability [40]. Figure $4 b-d$ illustrates such devices improvements. The planar-(n-i-p) architecture in Figure $4 \mathrm{~b}$ results from PSC devices without the mesoscopic metal oxide required in DSSCs as a structural scaffold. A planar architecture is a promising architecture for large surface area manufacturing on flexible substrates because this architecture is fabricated from lowtemperature preparation methods [41]. The planar-(n-i-p) devices are reported to reach high efficiencies of up to $23.6 \%$, slowly approaching the $25.5 \%$ of mesoscopic-(n-i-p) architecture. Although the (n-i-p)-device architecture demonstrates high efficiencies, their stability still suffers due to the negative impacts (e.g., degradation) imposed on the perovskite layer by the acidic and hydrophilic nature of the traditional Spiro-MeOTAD and PEDOT:PSS HTMs $[26,42,43]$. The planar- $(p-i-n)$ in Figure $4 c$ and mesoscopic-(p-i-n) in Figure $4 d$ are inverted structures of the conventional-(n-i-p) architecture, whereby the sequence of deposition is reversed. The inverted architecture partially overcomes the instability issues by reducing the corrosive nature of the HTMs on the device light-active layer.

(a) $n$-i-p mesoscopic

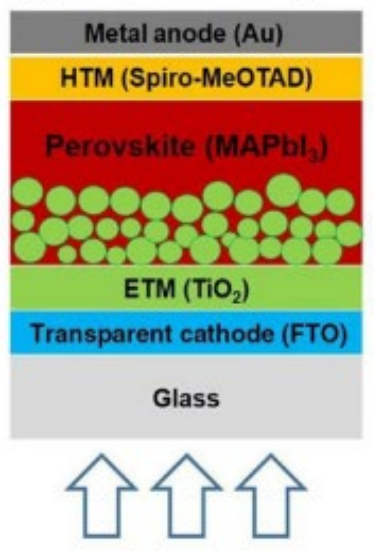

(b) n-i-p planar

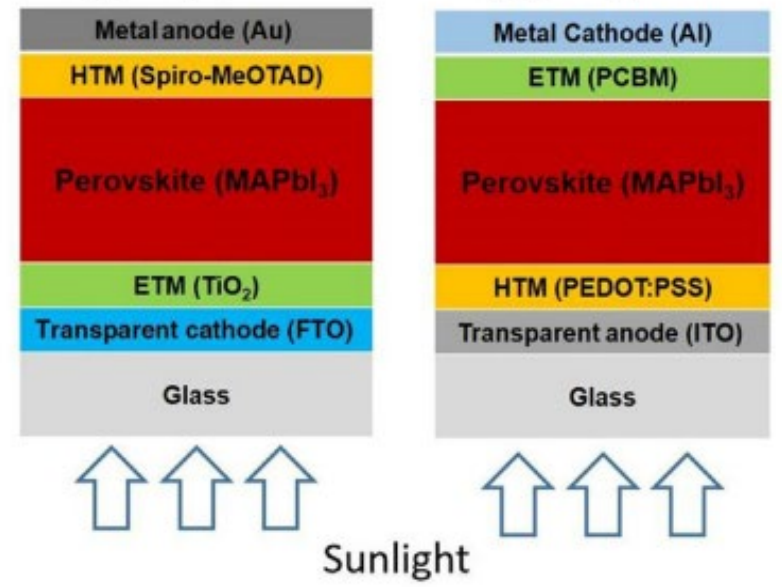

(d) p-i-n mesoscopic

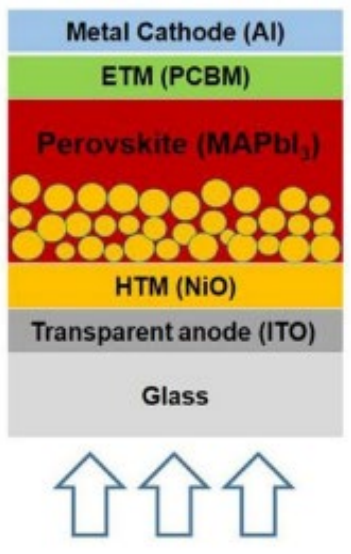

Figure 4. $(\mathbf{a}, \mathbf{b})$ represent simplified images of a conventional n-i-p PSC device architecture. (c,d) represent the inverted p-i-n PSC device architecture [40].

Optimizing the device thickness by removing the mesoporous ETM and the change in device architecture has shown to be efficient for high-performance PSCs. Another significant route for improving the device PCE and operational stability lies in designing the perovskite $\mathrm{ABX}_{3}$ composition from simple chemical approaches. Figure 5 shows the basis of $\mathrm{ABX}_{3}$ design. Figure $5 \mathrm{a}, \mathrm{b}$ present the IPCE and I-V characteristic performance from $\mathrm{MAPbI}_{3}$ and $\mathrm{MAPbBr}_{3}$ single halide PSCs. The distinctive difference in the iodide and bromide performance presented sufficient motivation in achieving hybrid materials of organic-inorganic perovskite materials through $\mathrm{ABX}_{3}$ designing [5]. From the IPCE curve, $\mathrm{MAPbBr}_{3}$ (solid line) shows a photon to the current conversion ratio of $62-65 \%$ at wavelengths less than $550 \mathrm{~nm}$. However, changes in behavior at higher wavelengths indicate that $\mathrm{MAPbBr}_{3}$ is most active at lower wavelengths, whereas $\mathrm{MAPbI}_{3}$ (dash line) shows a $45 \%$ conversion rate over a wide wavelength range of 450-750 nm. The good short circuit current of $10.8 \mathrm{mAcm}^{-2}$ in $\mathrm{MAPbI}_{3}$ and the good open-circuit voltage of $0.94 \mathrm{~V}$ in $\mathrm{MAPbBr}_{3}$ from the corresponding I-V curves are attributed to the long IPCE ratio in $\mathrm{MAPbI}_{3}$ and good electron transfer from the active layer LUMO to the ETM conduction band in $\mathrm{MAPbBr}_{3}$, respectively. This study paved a path for a multitude of ideas in varying the perovskite $\mathrm{ABX}_{3}$ crystal structure, resulting in hybrid perovskite materials of mixed-halide, mixed-cation, all organic, all-inorganic, perovskite-light-active thin films. 

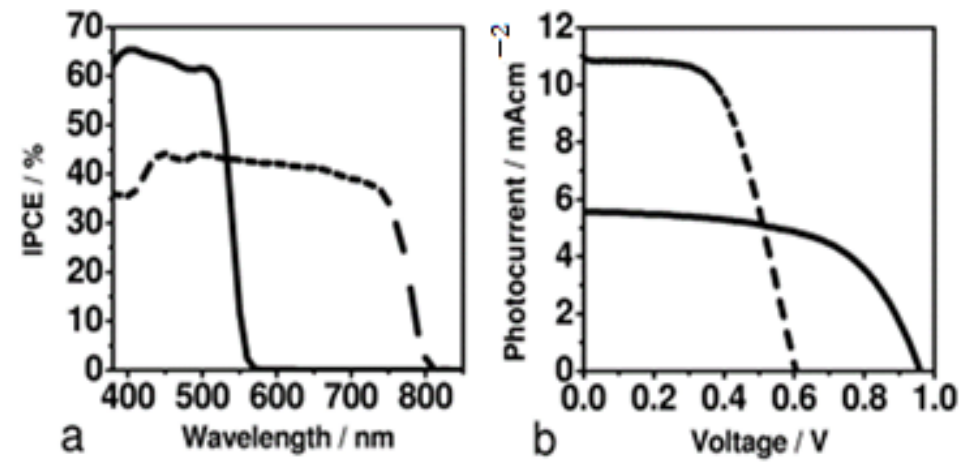

Figure 5. (a) IPCE and (b) I-V curve for $\mathrm{MAPbBr}_{3}$ (solid line) and $\mathrm{MAPbI}_{3}$ (solid line) [5].

Hybrids of mixed-halide PSCs result in synergistic properties not obtained in single halide PSCs. Docampo (2013) compared the optical and PV properties of planar $\mathrm{MAPbI}_{3}$ single halide and planar $\mathrm{MAPbI}_{3-\mathrm{x}} \mathrm{Cl}_{\mathrm{x}}$ mixed-halide PSCs prepared via a dip-coating solution of $\mathrm{PbI}_{2}$ thin films into precursor solutions containing (single-halide) MAI plus (mixed-halide) $\mathrm{MACl}$ at a controlled concentration ratio ( $\mathrm{wt} \%$ ), as shown in Figure 6a. It is observed that the PSC performance increases in mixed-halide perovskite systems (Table 1). In the time-resolved photoluminescence results reported in Figure 6b, the planar $\mathrm{MAPbI}_{3}$ device exhibits a short photoexcitation lifetime, minimizing the charge carrier diffusion length in the relatively thick $\mathrm{MAPbI}_{3}$ film. Remarkably, it is observed that the addition of $\mathrm{Cl}$ at small $\mathrm{wt} \%$ into the $\mathrm{MAPbI}_{3}$ composition increases the charge carrier lifetime, resulting in diffusion lengths that are a few nanometers greater than the $\mathrm{MAPbI}_{3-\mathrm{x}} \mathrm{Cl}_{\mathrm{x}}$ thickness. The corresponding I-V results are demonstrated in Figure $6 c$; the mixed-halide $\mathrm{MAPbI}_{3-\mathrm{x}} \mathrm{Cl}_{\mathrm{x}}$ PSC device reaches high short circuit current $\left(\mathrm{J}_{\mathrm{sc}}\right)$ and efficiency $(\eta)$ values of $22.9 \mathrm{mAcm}^{-2}$ and $15.41 \%$ in comparison to the low PV parameters in single-halide $\mathrm{MAPbI}_{3}$. This improved PSC performance is suggested to be attributed to the small average crystal size and minimum grain boundaries within the mixed halide promoting higher diffusion lengths. However, the study indicates that further addition of the second halide component (Cl) slightly decreases the device short circuit current and open-circuit voltage, therefore demonstrating that optimization in the preparation method is required for optimum device performance [20].

Table 1. Types of PSCs with device architecture "TCO/ETM/Perovskite layer/HTM/metal contact" varied by the perovskite layer, ETM and HTM [5,20,30,43-52].

\begin{tabular}{|c|c|c|c|c|c|c|c|}
\hline $\begin{array}{c}\text { Device } \\
\text { Variations }\end{array}$ & Type & $\mathbf{V}_{\mathbf{o c}}$ & $\mathrm{J}_{\mathrm{sc}}$ & FF & PCE & Year & Ref. \\
\hline $\begin{array}{l}\text { Single-halide } \\
\text { PSC }\end{array}$ & $\begin{array}{c}\mathrm{FTO} / \mathrm{m}-\mathrm{TiO}_{2} / \mathrm{MAPbBr}_{3} / \mathrm{LiBr} \mid \mathrm{Br}_{2} / \mathrm{Pt} \text {-FTO } \\
\mathrm{FTO} / \mathrm{m}-\mathrm{TiO}_{2} / \mathrm{MAPbI}_{3} / \mathrm{HTM} / \mathrm{LiI}^{\prime} \mathrm{I}_{2} / \mathrm{Pt} \text {-FTO }\end{array}$ & $\begin{array}{l}0.96 \\
0.61\end{array}$ & $\begin{array}{l}5.57 \\
11.0 \\
\end{array}$ & $\begin{array}{l}59.0 \\
57.0\end{array}$ & $\begin{array}{l}3.13 \\
3.81 \\
\end{array}$ & $\begin{array}{l}2009 \\
2009\end{array}$ & {$[2]$} \\
\hline \multirow{3}{*}{$\begin{array}{l}\text { Mixed-halide } \\
\text { PSC }\end{array}$} & $\begin{array}{c}\text { ITO/PCBM/MAPbI }{ }_{3-x} \mathrm{Cl}_{x} / \text { Spiro-MeOTAD/ } \\
\text { metal contact }\end{array}$ & 0.97 & 17.9 & 70.0 & 12.2 & 2013 & {$[20]$} \\
\hline & \multirow{2}{*}{$\begin{array}{c}\text { metal contact } \\
\mathrm{FTO} / \mathrm{TiO}_{2} / \mathrm{MAPbI}_{3-\mathrm{x}} \mathrm{Cl}_{\mathrm{x}} / \mathrm{PTAA} \mathrm{Au} \\
\mathrm{ITO} / \mathrm{ETM} / \mathrm{MAPb}\left(\mathrm{Br}_{\mathrm{x}} \mathrm{I}_{1-\mathrm{x}}\right)_{3-\mathrm{y}} \mathrm{Cl}_{\mathrm{y}} / \mathrm{HTM} / \\
\text { metal contact }\end{array}$} & 1.10 & 21.4 & 77.6 & 18.3 & 2016 & {$[40]$} \\
\hline & & 1.05 & 10.01 & 70.0 & 8.7 & 2014 & [41] \\
\hline \multirow{3}{*}{ Mixed cations } & $\begin{array}{c}\mathrm{FTO} / \mathrm{co}-\mathrm{TiO}_{2} / \mathrm{mp}- \\
\mathrm{TiO}_{2} /\left(\mathrm{FAPbI}_{3}\right)_{0.85}\left(\mathrm{MAPbBr}_{3}\right)_{0.15} / \text { Spiro- } \\
\text { MeOTAD } / \mathrm{Au}\end{array}$ & 1.15 & 22.7 & 76.0 & 20.2 & 2016 & [29] \\
\hline & $\begin{array}{c}\mathrm{FTO} / \mathrm{c}-\mathrm{TiO} 2 / \mathrm{m}_{-} \mathrm{TiO}_{2} / \mathrm{Cs} / \mathrm{FA} / \mathrm{MA} / \text { Spiro- } \\
\mathrm{MeOTAD} / \mathrm{Au}\end{array}$ & 1.14 & 23.6 & 77 & 20.8 & 2017 & [42] \\
\hline & $\left(\mathrm{Rb}_{0.1} \mathrm{Cs}_{0.05} \mathrm{FA}_{0.85}\right) \mathrm{Pb}\left(\mathrm{I}_{1-\mathrm{x}} \mathrm{Br}_{\mathrm{x}}\right)$ & 1.15 & 22.2 & 73.0 & 18.7 & 2016 & [43] \\
\hline $\begin{array}{l}\text { Metal Oxide } \\
\quad(\text { ETM) }\end{array}$ & $\begin{array}{l}\mathrm{ITO} / \mathrm{TiO}_{2} / \mathrm{MAPbI}_{3-\mathrm{x}} \mathrm{Cl}_{\mathrm{x}} / \text { Spiro-MeOTAD } / \mathrm{Ag} \\
\mathrm{ITO} / \mathrm{ZnO} / \mathrm{MAPbI}_{3} / \mathrm{Spiro}-\mathrm{MeOTAD} / \mathrm{Au} \\
\mathrm{FTO} / \mathrm{NiO} / \mathrm{MAPbI}_{3-\mathrm{x}} \mathrm{Cl}_{\mathrm{x}} / \mathrm{PCBM} / \mathrm{Al} \text { (inverted) }\end{array}$ & $\begin{array}{l}0.95 \\
0.87 \\
0.97\end{array}$ & $\begin{array}{l}21.4 \\
19.2 \\
15.89\end{array}$ & $\begin{array}{l}60.0 \\
67.6 \\
57\end{array}$ & $\begin{array}{l}12.2 \\
11.3 \\
8.78\end{array}$ & $\begin{array}{l}2014 \\
2016 \\
2014\end{array}$ & $\begin{array}{l}{[44]} \\
{[45]} \\
{[46]}\end{array}$ \\
\hline \multirow{3}{*}{ HTM } & \multirow{3}{*}{ 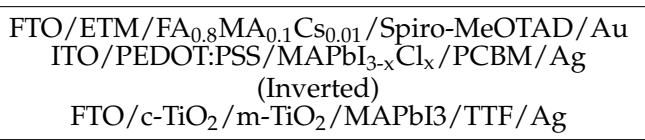 } & 1.16 & 21.5 & 73.0 & 18.1 & 2017 & [47] \\
\hline & & 1.11 & 20.11 & 80.6 & 16.5 & 2018 & {$[48]$} \\
\hline & & 0.86 & 19.9 & 64.4 & 11.0 & 2012 & [49] \\
\hline
\end{tabular}


(a)

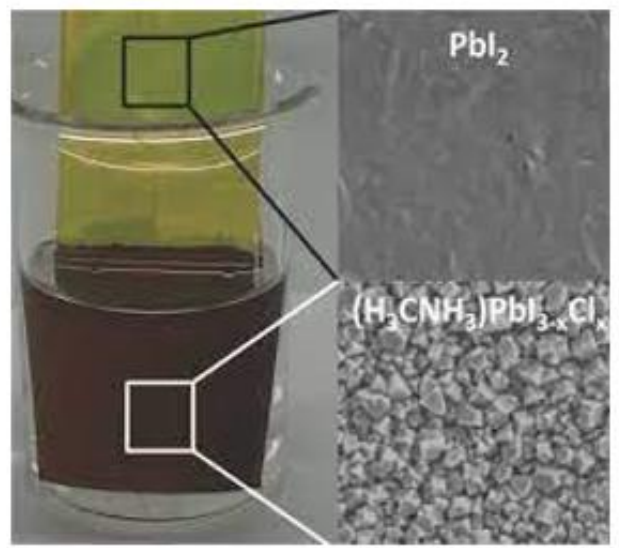

(b)

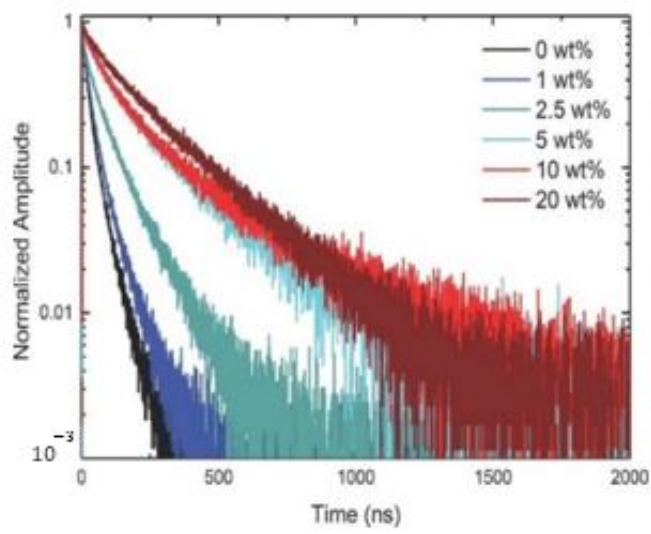

(c)

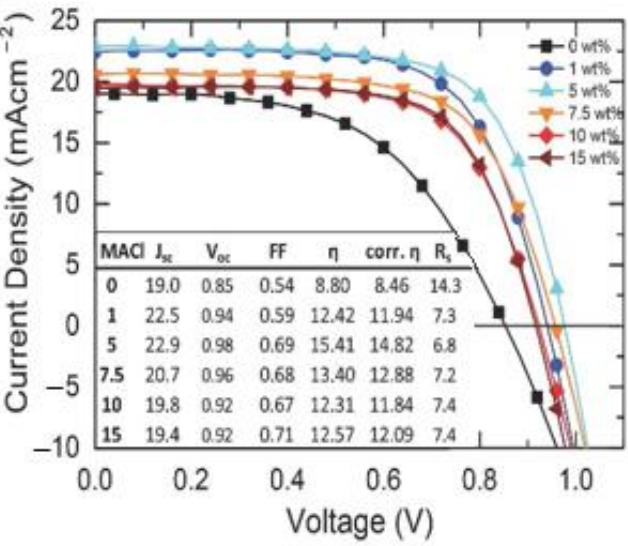

Figure 6. (a) Dip-coating solution preparation method for the perovskite films and the corresponding surface morphologies in $\mathrm{PbI}_{2}, \mathrm{MAPbI}_{3-\mathrm{x}} \mathrm{Cl}_{\mathrm{x}}$, and/or $\mathrm{MAPbI}_{3}$ thin films. (b) Time-resolved photoluminescence spectrum and (c) photovoltaic performance in planar heterojunction solar cells of $\mathrm{MAPbI}_{3}$ and $\mathrm{MAPbI}_{3-\mathrm{x}} \mathrm{Cl}_{\mathrm{x}}$ at various $\mathrm{wt} \%$ addition of $\mathrm{MACl}[20]$.

Further to the designing of $\mathrm{ABX}_{3}$, processing conditions such as thermal annealing, ageing, doping, moisture and solvent treatment strategies are used to optimize device performance during PSC fabrication. Adhyaksa (2016) studied the effect of ageing (a device placed in the dark at room temperature) on the diffusion length and bandgap energy of mixed $\mathrm{MAPb}\left(\mathrm{I}_{1-\mathrm{x}} \mathrm{Br}_{\mathrm{x}}\right)_{3}$ halide perovskite. Figure 7 a shows a plot of the mixed perovskite diffusion length $\mathrm{L}(\mathrm{nm})$ against bandgap energy $(\mathrm{eV})$ values; the insert images are the aged PSC thin films arranged according to their bandgap energies; the white and black dots present corresponding diffusion length and bandgap values for aged and non-aged PSCs films, respectively. It is noted in both cases that the bandgap structure is tuned by varying the bromine (Br) and iodide (I) weight fractions. Bandgap values in the thin films increase with increasing $\mathrm{Br}$ content. A distinctive phase change is observed by the color change towards high bandgap values from black to yellow, indicating that the devices can be optimized to absorb specific regions in the solar spectrum. The aged film at $\sim 1.8 \mathrm{eV}$ recorded the highest diffusion length, double of the non-aged films. This study, therefore, shows that the application of processing conditions on either single- or mixedhalide perovskite thin films offers the ability to fine-tune the resulting perovskite optical properties for better and desired performances [28,53]. 
(a)

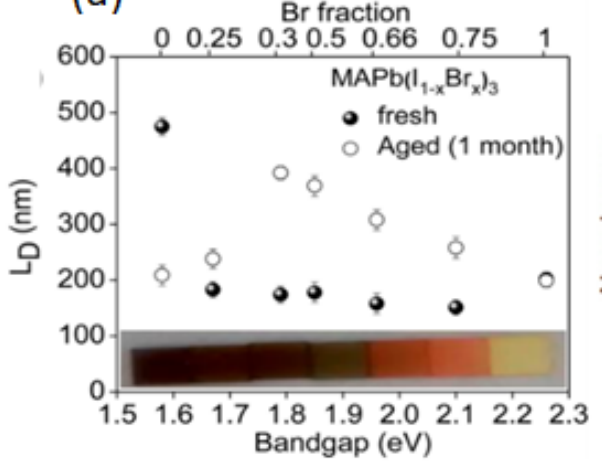

(c) (b)

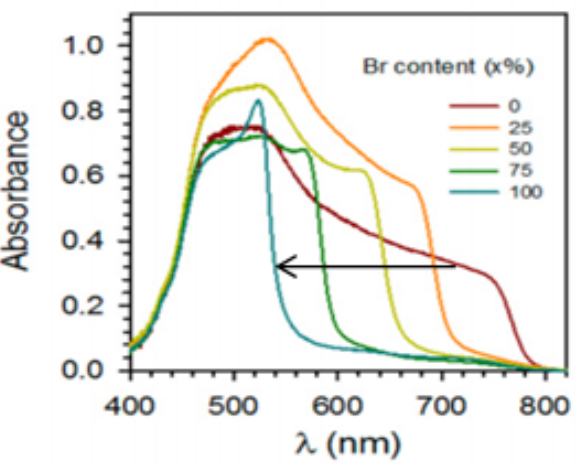

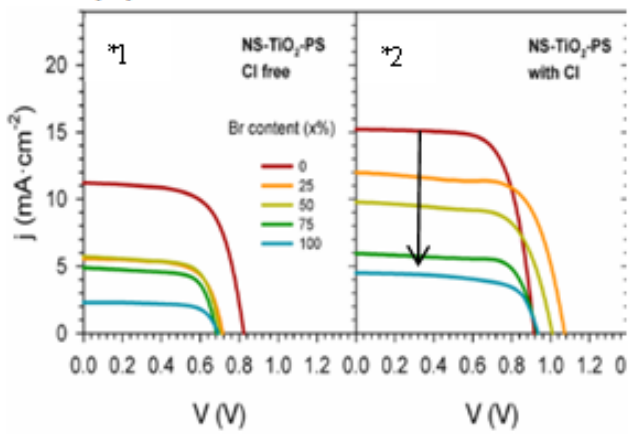

Figure 7. (a) A plot of diffusion length ( $\mathrm{L} \mathrm{nm}$ ) against bandgap energies of aged and non-aged $\mathrm{MAPb}\left(\mathrm{I}_{1-\mathrm{x}} \mathrm{Br}_{\mathrm{x}}\right)_{3}$ perovskite thin films. (b) Absorption spectra of mixed-halide perovskite film. (c) I-V curve in a hybrid mixed-halide PSC [28,47].

In a similar study, Suarez (2014) characterized the effect of halogen $(x \%=I, B r$, and $\mathrm{Cl}$ ) composition in mixed-halide PSCs' optical and PV properties. In Figure 7b, a shift towards lower wavelengths is observed in the absorption spectra as indicated by the arrow. This absorption behavior further confirms the successful bandgap tunability in Figure 7a reported above [47]. In Figure $7 \mathrm{c}^{*} 1$, a significant reduction in $\mathrm{J}_{\mathrm{sc}}$ and $\mathrm{V}_{\mathrm{oc}}$ is observed. This low device performance is attributed to the shift towards lower wavelengths reported from the absorption spectra in Figure $7 \mathrm{~b}$. Figure $7 \mathrm{c}^{*} 2$ shows an appreciable increase in $\mathrm{J}_{\mathrm{sc}}$ and $\mathrm{V}_{\mathrm{oc}}$ with the introduction of a third halogen $(\mathrm{Cl})$ component. However, the shift in absorption further persists to decrease the device performance in the triple halide PSCs.

The complex perovskite crystal structure $\mathrm{ABX}_{3}$ offers the advantage of modelling the resulting absorber layer from stochiometric solution preparation methods [54,55]. Singh (2017) studied cell properties of a mixed-cation (Cs/FA/MA) perovskite device and obtained characteristic

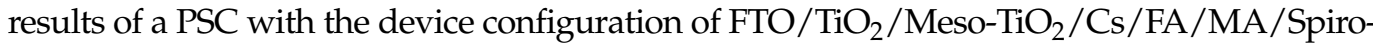
$\mathrm{MeOTAD} / \mathrm{Au}$ as shown by the cross-sectional image in Figure 8d [48]. In previous studies of MA/FA perovskite thin films, it is reported that the $\mathrm{MA}^{+}$cation at small ratios acts as a $\mathrm{FA}^{+}$nucleating site, increasing the degree of crystallinity in the FA photoactive film, thus also enhancing the light sensitivity of the ${ }^{+}$FA thin films. However, the MA/FA systems showed traces of small phase impurities that eventually affect overall morphology and stability. It is reported that the incorporation of cesium (Cs) inorganic cation improves MA/FA intrinsic properties [56,57]. 
(e)

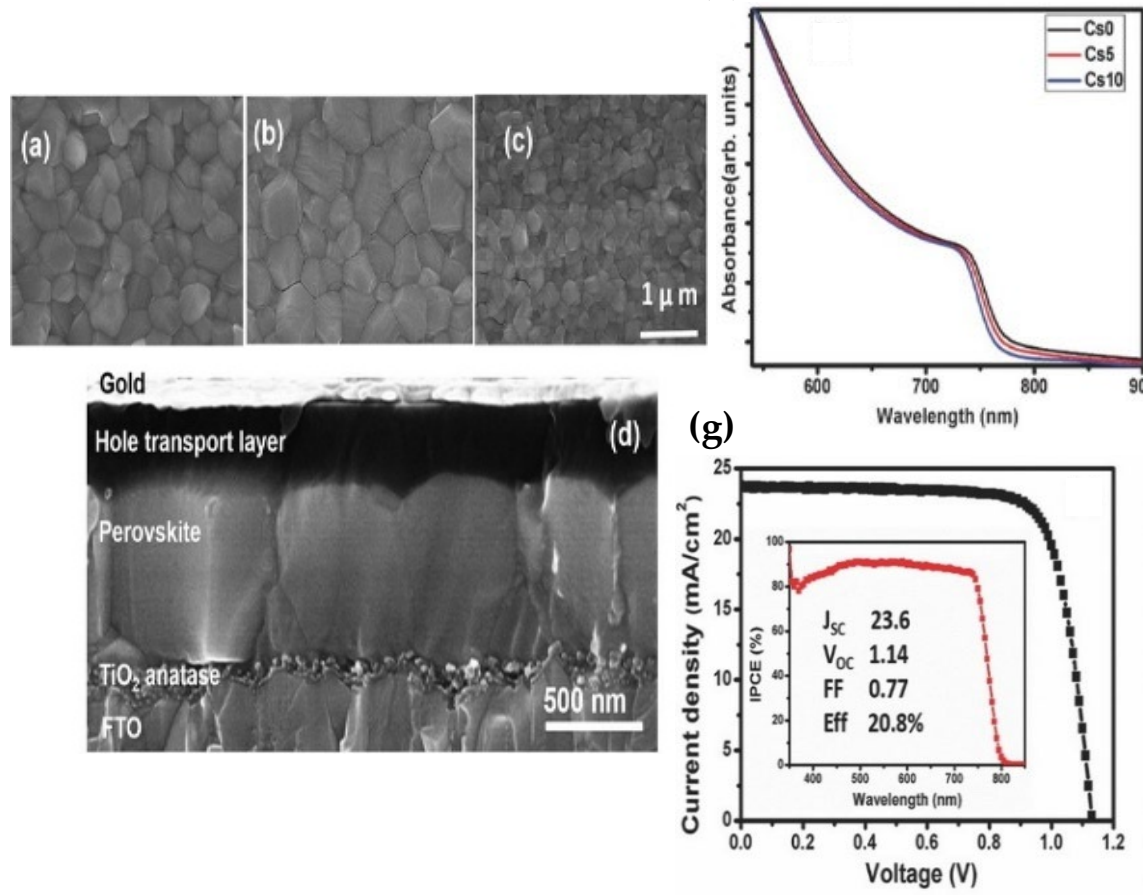

(f)

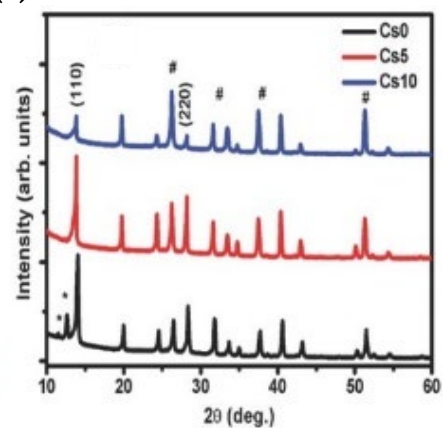

(h)

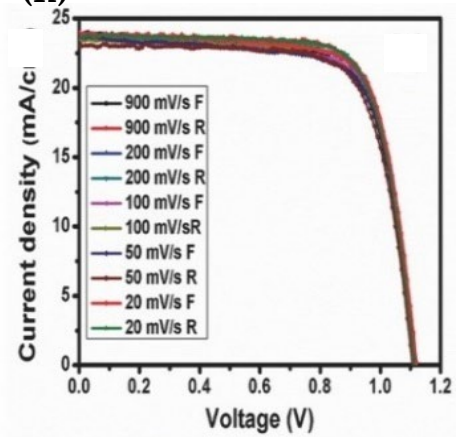

Figure 8. Characterized performance of triple cation perovskite solar cell. (a-d) SEM micrographs images; (a) Cs0/MA/FA, (b) Cs5/MA/FA; (c) Cs10/MA/FA; (d) cross sectional area at Cs5/MA/F; (e) absorption spectrum; (f) XRD pattern of Cs/MA/FA at 0, 5 to $10 \mathrm{wt} \% \mathrm{Cs}$ addition; (g,h) I-V and IPCE curves [48].

Figure 8a shows an SEM micrograph image of a neat MA/FA system with a bumpy distribution of grains and the presence of surface grooves, indicating a low level of adhesion between grain interfaces; in Figure $8 \mathrm{~b}$, at a $5 \mathrm{wt} \%$ addition of Cs, the crystal grains increase in size and the surface boundary between the grain becomes diluted, this might suggest an improved surface adhesion between grains and, hence, a high degree of crystallinity. However, at high additions of $10 \mathrm{wt} \% \mathrm{Cs}$, as indicated in Figure $8 \mathrm{c}$, the surface adhesion disappears and grains are reduced to a small particle size, increasing the possibility of crystal defects. Figure 8 e shows the characteristic absorption band of a perovskite absorber layer with absorption over the UV-vis spectrum. Figure 8 f shows XRD patterns at 0,5 , and $10 \mathrm{wt} \% \mathrm{Cs}$ addition, all showing a perovskite characteristic peak at a $\sim 14^{\circ}$ diffraction angle, corresponding to the (110) plane. Defect peaks at diffraction angles lower than $14^{\circ}$ are seen for the neat MA/FA system; this might be assigned to the surface boundaries between grains. At $5 \mathrm{wt} \%$ Cs addition, the defect peaks disappear and a there is a significant increase in perovskite peak intensity at a $14^{\circ}$ diffraction angle, suggesting an increase in crystallinity. This behavior is however not favored for higher concentrations of Cs addition. The inorganic Cs metal encourages crystallization and increases the device stability, illustrated by the occurrence of little to no J-V hysteresis between the forward and reverse bias measurements, as shown in Figure $8 \mathrm{~h}$.

Electricity is generated by the direct absorption of sunlight in a PV solar cell. The absorbed light creates electron-hole pairs (excitons) in the absorber layer, electrons are then collected at the anode electrode to the external circuit and through an electrical load. Electrons are thereafter reinjected into the absorber layer by a cathode counter electrode where recombination with holes occurs. The energy difference of the electron at the anode and cathode is used to determine the open-circuit voltage $\left(V_{o c}\right)$ [58]. Figure 9 a underlines the basic cell operation of a perovskite solar cell. Nagarjuna (2015) studied the effect of transporting materials in a PSC and reported that the correct choice of cell transporting material is, at most, necessary for better PCE, $\mathrm{FF}$, and $\mathrm{V}_{\mathrm{oc}}$ [59]. A compatible transporting 
material should have high charge extraction, high mobility, and proper energy alignment with the absorber layer at their interface, as indicated in Figure 9b. The traditional materials used as ETM and HTM in PSCs include titanium dioxide $\left(\mathrm{TiO}_{2}\right)$ and Spiro-MeOTAD, respectively. Other common alternatives such as aluminium oxide $\left(\mathrm{Al}_{2} \mathrm{O}_{3}\right)$, zinc oxide $(\mathrm{ZnO})$, and PCBM are used as ETMs, while copper iodide (CuI), nickel oxide (NiO), PEDOT: PSS, and poly(triarylamine) (PTAA) materials are common alternative HTMs.

(a)

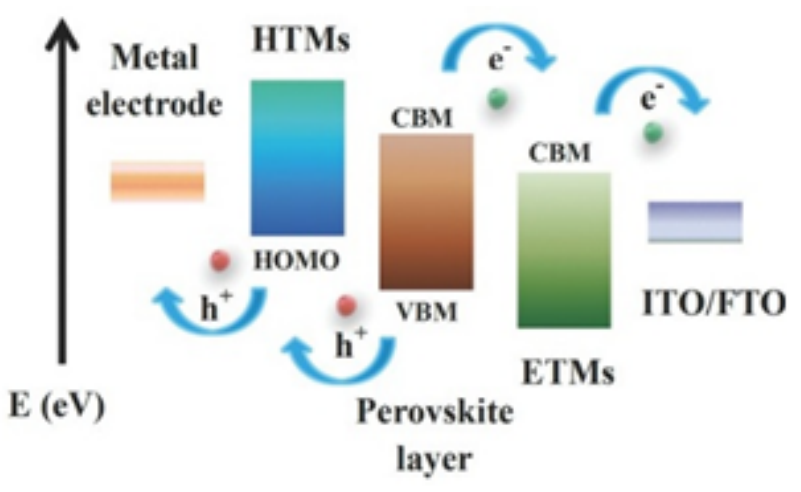

(b)

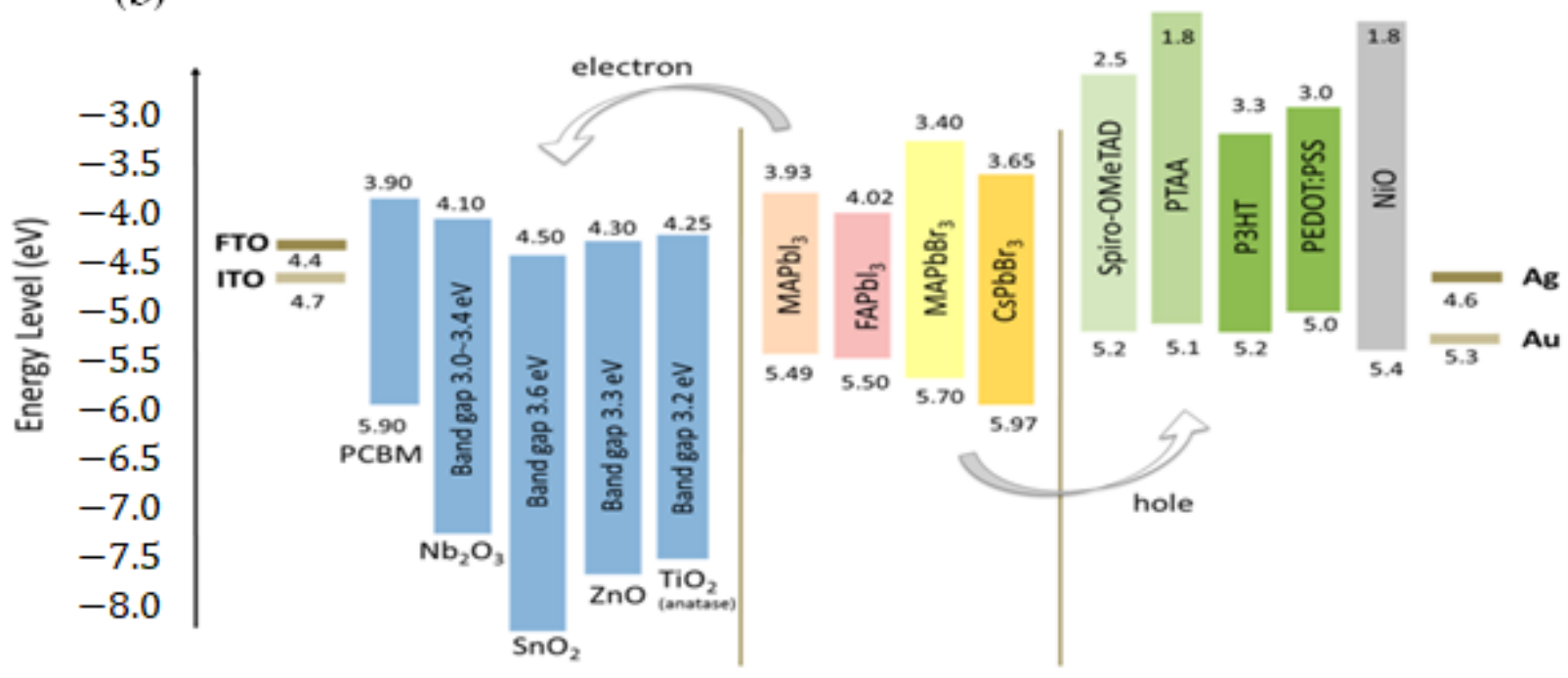

Figure 9. (a) Schematic diagram showing the basic device operation in a PSC. (b) Simplified energy alignment of possible ETM and HTM materials in PSC applications [19,60].

\section{Fabrication Methods}

As already discussed, PSCs have taken many routes to achieve high performances, such as the device transition from sensitized solar cells to the recent planar thin-film solar cells, preparation of hybrid perovskite-light-active materials, the use of processing conditions, and lastly the use of different charge ETMs and HTMs. In addition, PSC fabrication methods play a role in high-quality perovskite films.

\subsection{One-Step Method}

The one-step deposition method involves spin coating a perovskite precursor solution onto a pre-treated transparent conductive oxide (TCO) substrate followed by annealing to form the perovskite active layer, as shown in Figure 10a. This is the widely used deposition method due to its simplicity and low production cost for small, lab-based PSCs, and is not suitable for large-surface-area device fabrications. To form a perovskite layer of crystal structure $\mathrm{ABX}_{3}$, organic (e.g., MAI/FAI) and inorganic (e.g., $\mathrm{PbX}_{2} / \mathrm{SnX}_{2}$ ) halides are dissolved into a common dipolar aprotic solvent, such as dimethyl sulfoxide (DMSO), dimethylformamide (DMF), or $\gamma$-butyrolactone (GBL), then spin coated onto an ETMbearing conductive substrate. The early PSC fabrication that triggered research interest was 
achieved through one-step spin coating of organic salts (MABr and MAI) together with inorganic salts $\left(\mathrm{PbBr}_{2}\right.$ and $\left.\mathrm{PbCl}_{2}\right)$, reaching efficiencies of $3.31 \%$ and $3.81 \%$ in the resulting $\mathrm{MAPbBr}_{3}$ and $\mathrm{MAPbI}_{3}$ PSCs, respectively [5]. In a later study, Miyasaka (2012) reported efficiencies of up to $10.9 \%$ by spin coating a solution of mixed-halide perovskite precursor over a mesoporous $\mathrm{Al}_{2} \mathrm{O}_{3}$ scaffold [7].

(a)

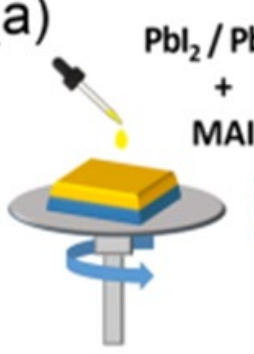

(c)

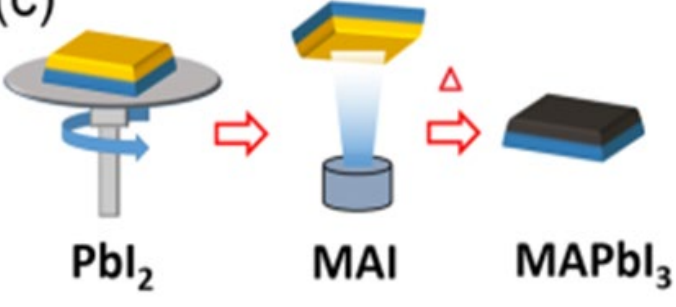

(b)

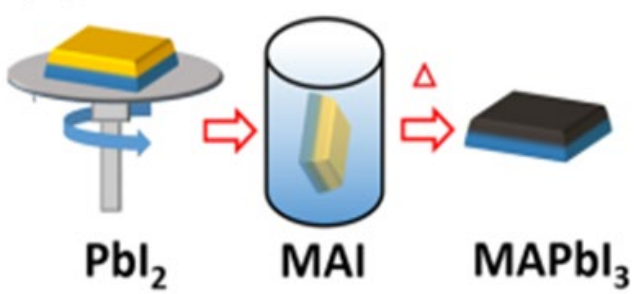

(d)

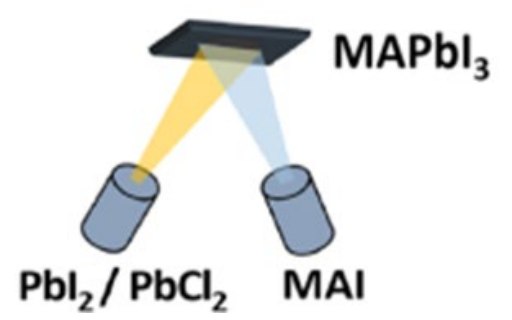

Figure 10. Schematic representation of perovskite solar cell fabrication methods. (a) One-step method; (b) two-step method; (c) vapor-assisted solution method; (d) thermal vapor deposition method. Precursor concentrations, coating dipping time, spin coating time, and spinning rates are perovskite film quality or morphology controlling parameters during fabrication [40].

In the one-step deposition method, the solution's ionic strength and post-annealing improve the perovskite crystal formation [61]. However, drawbacks such as lack of control over film uniformity and morphology are observed. Chen (2015) fabricated an inverted (p-i-n) perovskite device with a $210 \mathrm{~nm}$-thick perovskite by one-step spin coating and acquired $\mathrm{PCE}=11.99 \%, \mathrm{~V}_{\mathrm{OC}}=0.81 \mathrm{~V}$ and $\mathrm{J}_{\mathrm{SC}}=21.9 \mathrm{mAcm}^{-2}$. Figure 11 a shows XRD peaks located at $28.39^{\circ}$ and $31.86^{\circ}$ diffraction angles, indicating perovskite crystal formation and suggesting that the deposition solvents did not destroy the perovskite crystal structure [62]. Despite showing good device efficiencies from 3.8 to $11.99 \%$, the SEM surface image of the perovskite film shown in Figure $11 \mathrm{~b}$ demonstrates the presence of pinholes caused by incomplete crystallization and distribution of non-uniform grains along the film morphology in the one-step method.

Zhang (2019) worked on improving the perovskite surface morphology by using binary solvent engineering systems during the perovskite one-step deposition. The technique offers control over the perovskite crystal formation, allowing complete and well-oriented homogeneous perovskite films [39]. This unique control over the perovskite morphology is achieved by a mixture of solvents such as the above mentioned DMF, DMSO, and GBL $[39,63]$. Figure 11c-e show AFM images at different DMF/DMSO solvent ratios of 1:0, 3:1, and 1:3, denoted as FO10, FO31, and FO13, respectively. With the presence of only DMF in Figure 11c, the AFM image reveals similar results reported in Figure 11b. The addition of a second solvent at a solvent ratio of 3:1 and 1:3 assists the film to eliminate the observed morphology cracks, pinholes, and incomplete crystallization defects. The volatile DMF solvent activates a homogeneous perovskite crystal nucleation and the presence of DMSO helps with crystal growth in an ordered orientation. Hence, the observed large, smooth, and closely packed perovskite grain morphologies in Figure 11e. In a similar study using a solvent mixture of GBL/DMSO at a solvent ratio of 7:3, Jeon (2014) acquired 16.2\% efficiencies with no hysteresis in forward and reverse bias I-V measurements [63]. 

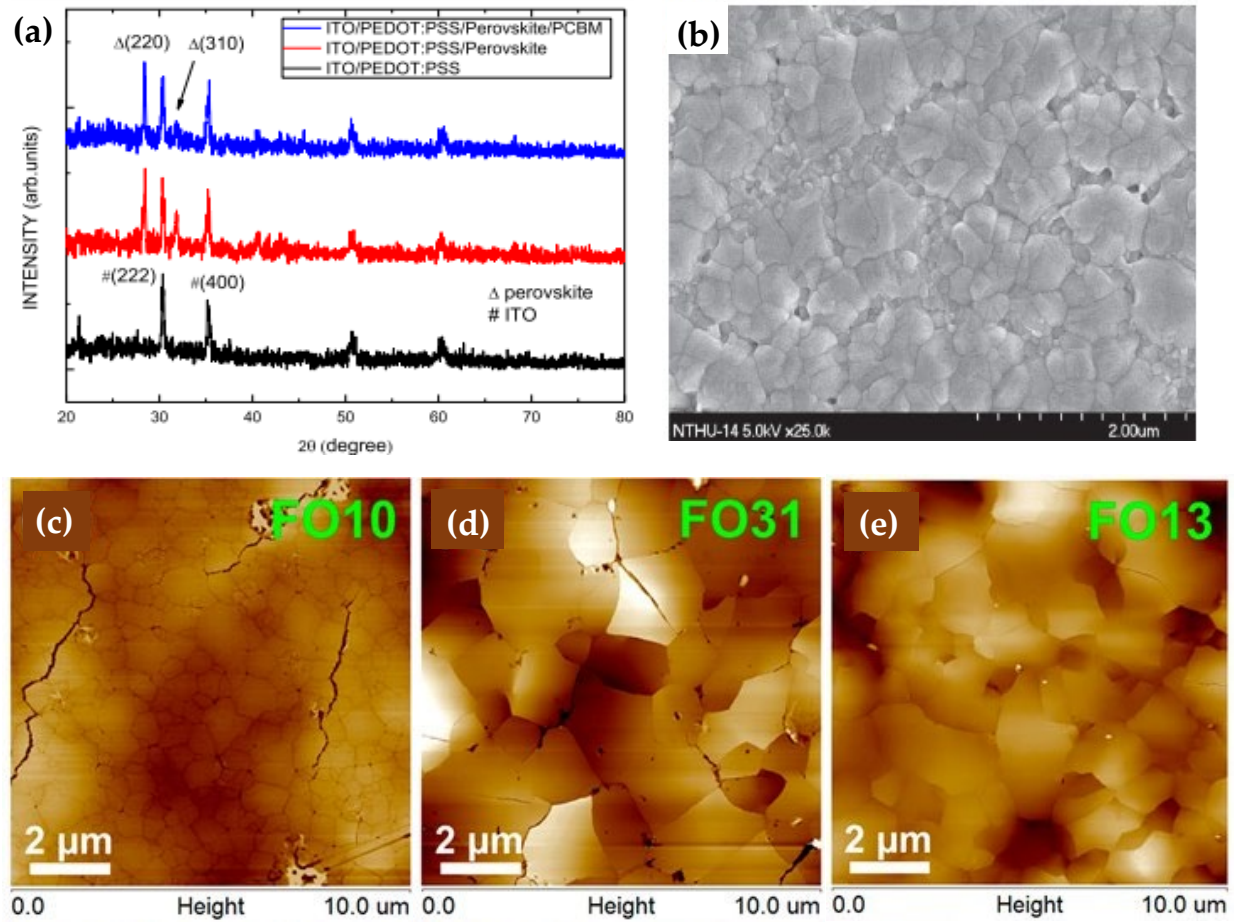

Figure 11. (a) X-ray diffraction patterns; (b) SEM micrograph; (c-e) AFM images [39,62].

\subsection{Two-Step Method}

The two-step fabrication or sequential fabrication method involves the spin coating of individual organic (MAI/FAI) and inorganic $\left(\mathrm{PbX}_{2} / \mathrm{SnX}_{2}\right)$ precursor solutions. This method offers the advantage of being able to control the surface morphology and film quality by optimizing precursor concentrations, dip-coating or spin-coating time, and spinning rates during the deposition of either organic or inorganic halide precursor. In the two-step method, the first step of deposition is spin coating the inorganic halide $\left(\mathrm{PbX}_{2}\right)$ on a substrate; then, the second step of deposition follows by either (i) dipping the $\mathrm{PbX}_{2}$-coated substrate into the organic MAI solution or (ii) spin coating the organic MAI solution over the $\mathrm{PbX}_{2}$ (see Figure 10b) [64]. Burschka (2013) used the two-step method to fabricate a PSC with PCE $=15.0 \%$. The study confirms a better control of device morphology from the XRD analysis and SEM cross-sectional micrographs of the device [65]. Firstly, the reported cross-sectional SEM images show the introduction of $\mathrm{PbI}_{2}$ into the nanoporous $\mathrm{TiO}_{2}$ film. This is confirmed by the formation of a single layer of $\mathrm{TiO}_{2} / \mathrm{PbI}_{2}$ with complete $\mathrm{PbI}_{2}$ crystal absorption, indicating successful $\mathrm{PbI}_{2}$ deposition onto $\mathrm{TiO}_{2}$ nanopores. The XRD pattern shows a characteristic perovskite peak at $14^{\circ}$ diffraction angles, confirming the formation of the perovskite absorber layer upon the second step deposition of MAI by (i) dip coating $\mathrm{TiO}_{2} / \mathrm{PbI}_{2}$ bearing substrate.

The presence of $\mathrm{PbI}_{2}$ residuals reduces the solar cell light-harvesting ability and charge carrier transport; hence, it reduces the overall PSC performance $[66,67]$. Similar to the onestep deposition method above, solvent engineering and the use of additives may be applied to overcome this fabrication drawback in the two-step method. $\mathrm{Li}$ (2015) reported a solvent mixture based on DMF and DMSO in $\mathrm{PbI}_{2}$ powder dissolution. The DMSO in the solvent mixture prevents early $\mathrm{PbI}_{2}$ crystallization and further acts as an intermediate exchange agent with $\mathrm{MAI}$ during $\mathrm{MAPbI}_{3}$ film formation. Low temperature and low coating time of MAI during the second step of deposition results in perovskite crystal formation only at the $\mathrm{PbI}_{2}$ surface which blocks further MAI infiltration into the $\mathrm{PbI}_{2}$ lattice. Such mass infiltration forms a rough surface structure with the presence of voids and pinholes $[68,69]$. 


\subsection{Vapor-Assisted Solution Method}

The vapor-assisted solution deposition method is considered a modification of the two-step method which improves the infiltration of the precursor solutions. The only difference between vapor-assisted solution and two-step method is that, during the second step of deposition, a vapor phase of either MAI/FAI is reacted with the $\mathrm{PbI}_{2}$ film (see Figure 10c) $[64,70]$. Chen (2015) investigated the performance of PSCs prepared by the two-step and vapor-assisted solution method and reported that PSCs fabricated from different techniques result in different properties. Flat films fabricated via vapor-assisted deposition show high surface coverage and pore filling of the mesoporous $\mathrm{TiO}_{2}$. The device performance records a high $\mathrm{V}_{\mathrm{oc}}$ of $0.96 \mathrm{~V}$ and an IPCE value of $81 \%$ over a $400-740 \mathrm{~nm}$ wavelength range. Photoluminescence (PL) spectra showed an intense peak in the two-step fabricated film, confirming defect densities caused by poor surface coverage [71]. In this study, the vapor-assisted solution method is shown to have high device efficiencies in comparison to the two-step method. The disadvantage of the vapor-assisted method is that the deposition of MAI vapor is time consuming $[72,73]$.

\subsection{Thermal Vapour Deposition Method}

The thermal vapor deposition method involves the simultaneous deposition of the organic (e.g., MAI or FAI) and inorganic (e.g., $\mathrm{PbI}_{2} / \mathrm{PbCl}_{2}$ ) halides in the vapor phase on a rotating substrate (see Figure 10d). This method offers a uniform surface morphology due to the ease of control over precursor depositing parameters and the speed of rotating substrate [29]. Liu (2013) reported a planar mixed-halide PSC recording efficiencies of up to $15.4 \%$. The $\mathrm{MAPbI}_{3-\mathrm{x}} \mathrm{Cl}_{\mathrm{x}}$ perovskite thin films were prepared from vapor deposition of MAI and $\mathrm{PbCl}_{2}$ precursor powder materials at a 4:1 deposition ratio [74]. In an attempt to produce a large-surface-area PSC device, Liang (2018) reported a large-scale PSC with a surface area of $100 \mathrm{~cm}^{2}$ (see Figure 12a) [75]. The device showed a PCE equal to $7.73 \%$. This study serves as a benchmark for the fabrication of commercial PSC through thermal vapor deposition. The device maintained a uniform composition throughout the film with no presence of impurities and subsequently high solar cell performance. Figure 12c depicts consistent XRD patterns at different regions of the solar cell marked A, B, C, E, and D, as shown in Figure 12b.

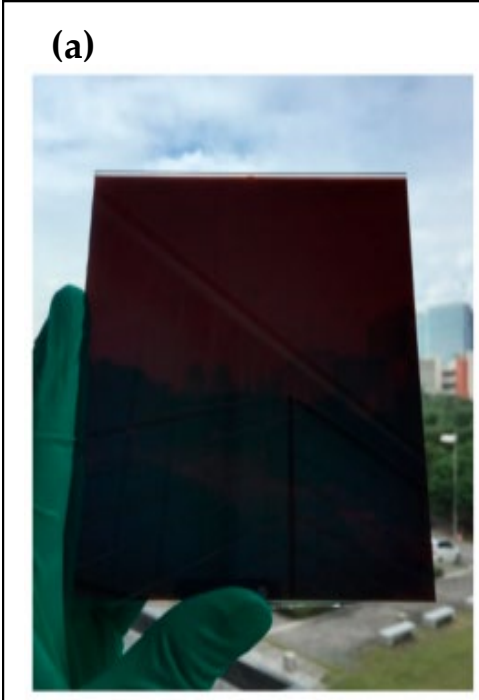

(b)

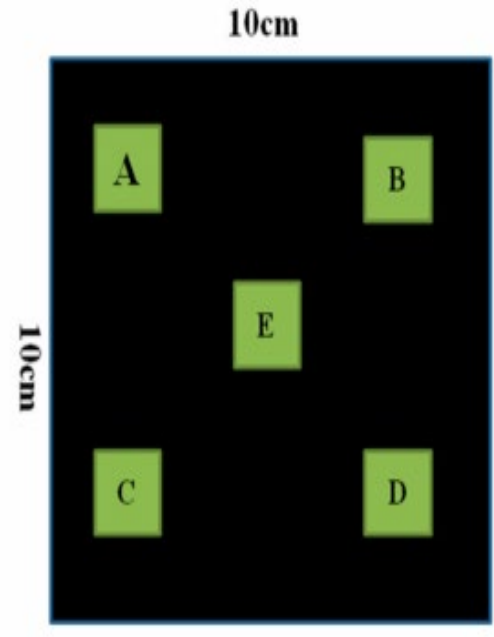

(c)

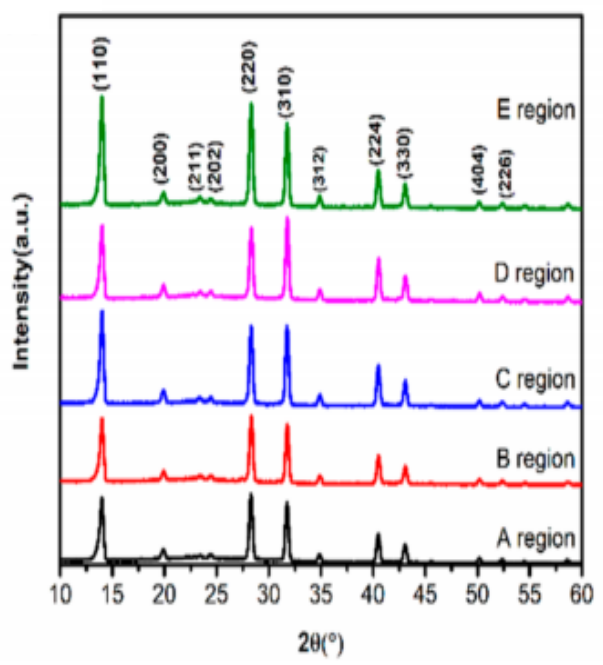

Figure 12. Low resolution images $(\mathbf{a}, \mathbf{b})$ of the $100 \mathrm{~cm}^{2}$ PSC prepared by the thermal-vapor-deposited method. (c) XRD patterns at the marked regions A, B, C, D, and E [75]. 


\section{Device Challenges}

\subsection{Perovskite Solar Cell Device Stability}

The development of the PSCs in the past decade has shown a massive improvement in efficiency over a short period in comparison with other existing solar cells. PSCs have already surpassed the performance of commercially available silicon-based PVs, making them the future of solar energy. However, the device's lifespan is below the required 25 years for a normal PV cell, ranging from days to months. The degradation of PSCs performance suggests that device instability stands in the way of commercialization [76]. Therefore, it is necessary to understand PSC degradation mechanics to improve the device's flaws. In the characterization of perovskite cell stability, the device is subjected to harsh environments in order to obtain superior performance under normal conditions. The degradation response results from failure of device components caused by external factors (moisture, oxygen, temperature, and UV radiation), internal factors (crystal structure, ion migration, and interfacial contact), the constituting materials, device architecture, and fabrication process. Therefore, it is important to note that PSC stability is affected by a variety of factors, suggesting that it is necessary to further study PSCs thoroughly and develop standard procedures and protocols towards building a fully functional and stable device.

\subsubsection{Stability in the Perovskite Crystal Structure $\left(\mathrm{ABX}_{3}\right)$}

The stability of the perovskite crystal structure is determined using the Goldschmidt tolerance factor $(t)$, shown by Equation (1). The cubic $(\alpha)$ phase is the most stable crystal structure, followed by the tetragonal $(\beta)$ phase; the least stable crystal structure is the orthorhombic $(\gamma)$ phase. In any crystal structure, the tolerance factor depends on the $\mathrm{ABX}_{3}$ constituting organic (e.g., $\mathrm{MA}^{+}=\mathrm{r}_{\mathrm{A}}$ ), inorganic (e.g., $\mathrm{Pb}^{2+}=\mathrm{r}_{\mathrm{B}}$ ) and halogen (e.g., $\mathrm{I}^{-}=\mathrm{r}_{0}$ ) ionic radius [77]. Further research has revealed that the crystal structure stability is also affected by changes in temperature and pressure. In the study to investigate the effect of temperature on perovskite crystal structure, Cojocaru (2015) reported a $\mathrm{MAPbI}_{3}$ phase transition from tetragonal to cubic at temperatures greater than $55^{\circ} \mathrm{C}$. In Figure $13 \mathrm{a}$, the $X R D$ results confirm a tetragonal phase with perovskite characteristic diffraction angles at $14.1^{\circ}, 28.5^{\circ}$, and $43.3^{\circ}$ associated with the (110), (220), and (330) planes, respectively [78]. An increase in sample temperature affects the crystal shape, as illustrated in Figure 13b-d; the perovskite diffraction peaks shift to lower diffraction angles as the temperature is increased. The observed shift in the XRD peaks suggests the rearrangement of the crystal lattice. Figure 13b-d show the phase transition from a tetragonal phase to a lower diffraction angle cubic phase for samples heated in a temperature range of -95 to $100{ }^{\circ} \mathrm{C}$. In another study, Gratzel (1998) reported the thermal stability of $\mathrm{FAPbI}_{3}$. The $\mathrm{FAPbI}_{3}$ has higher thermal stability than $\mathrm{MAPbI}_{3}$ due to its tetragonal-cubic phase transition occurring at a high temperature of $150^{\circ} \mathrm{C}$ [79]. Therefore, in conclusion, a stable perovskite crystal structure is found at high temperatures and depends on the perovskite material in question.

The perovskite crystal structure response mechanism to pressure remains a mystery, as there is an unusual sequence of phase transition with an increase in pressure. For example, phase transitions such as tetragonal-cubic-orthorhombic, orthorhombic-tetragonal-cubic, and vice versa, are observed [80,81]. Jaffe (2016) conducted a study to understand $\mathrm{MAPbX}_{3}$ $(\mathrm{X}=\mathrm{Br}$ and I) perovskite crystal structure response to compression. Single crystal and powder X-ray diffraction (SCXRD and PXRD) techniques were used to characterize material crystal structure at ambient pressure and during high-pressure conditions [82]. The applied pressure had a significant effect on $\mathrm{Pb}-\mathrm{X}(\mathrm{X}=\mathrm{Br}$ and $\mathrm{I})$ bond lengths, volume and $\alpha-\beta$ phase transition. Figure $14 \mathrm{a}, \mathrm{b}$ show $\mathrm{MAPbX}_{3}$ SCXRD crystal structure model at ambient and high pressure. Figure $14 \mathrm{c}, \mathrm{d}$ show $\mathrm{MAPbX}_{3}$ PXRD diffraction patterns under a continuous increase in pressure (compression). At ambient pressure, $\mathrm{Pb}-\mathrm{X}-\mathrm{Pb}$ bond angles are at $180^{\circ}$ as shown in Figure $14 \mathrm{a}, \mathrm{b}$, compression results in the $\mathrm{Pb}-\mathrm{X}-\mathrm{Pb}$ bond angle contraction to angles $<180^{\circ}$, reduces $\mathrm{Pb}-\mathrm{X}$ bong length, and subsequently $\alpha-\beta$ phase transitions at pressures greater than 1.7 and $0.7 \mathrm{GPa}$ for $\mathrm{MAPbBr}_{3}$ and $\mathrm{MAPbI}_{3}$ perovskite 
crystal structures, respectively. Further compression of the $\beta$ phase results in further bond length and volume reductions. Strong intermolecular interactions develop due to the tight conformation in the $\mathrm{ABX}_{3}$ unit cell. The XRD patterns in Figure $14 \mathrm{c}$, d show changes in the $\mathrm{MAPbBr}_{3}$ and $\mathrm{MAPbI}_{3}$ crystal structure as pressure is continuously increased up to a maximum pressure of $9 \mathrm{GPa}$. In both perovskite materials, $\mathrm{MAPbX}_{3}(\mathrm{X}=\mathrm{Br}$ and $\mathrm{I})$ normal perovskite behavior is observed at low pressures, as indicated by arrow 1 . An increase in pressure destroys the normal perovskite crystal structure behavior; hence, the disappearance of perovskite characteristic diffraction peaks indicated by arrow 2 . Arrow 3 shows that the perovskite materials restores to the initial configuration or normal behavior upon decompression. Therefore, in conclusion, the perovskite crystal structure does respond to pressure. Subjecting the material to high pressures suppresses or reduces the perovskite structural features. Therefore, a stable perovskite crystal structure ( $\alpha$ phase) is obtained at relatively low pressures.

(a)
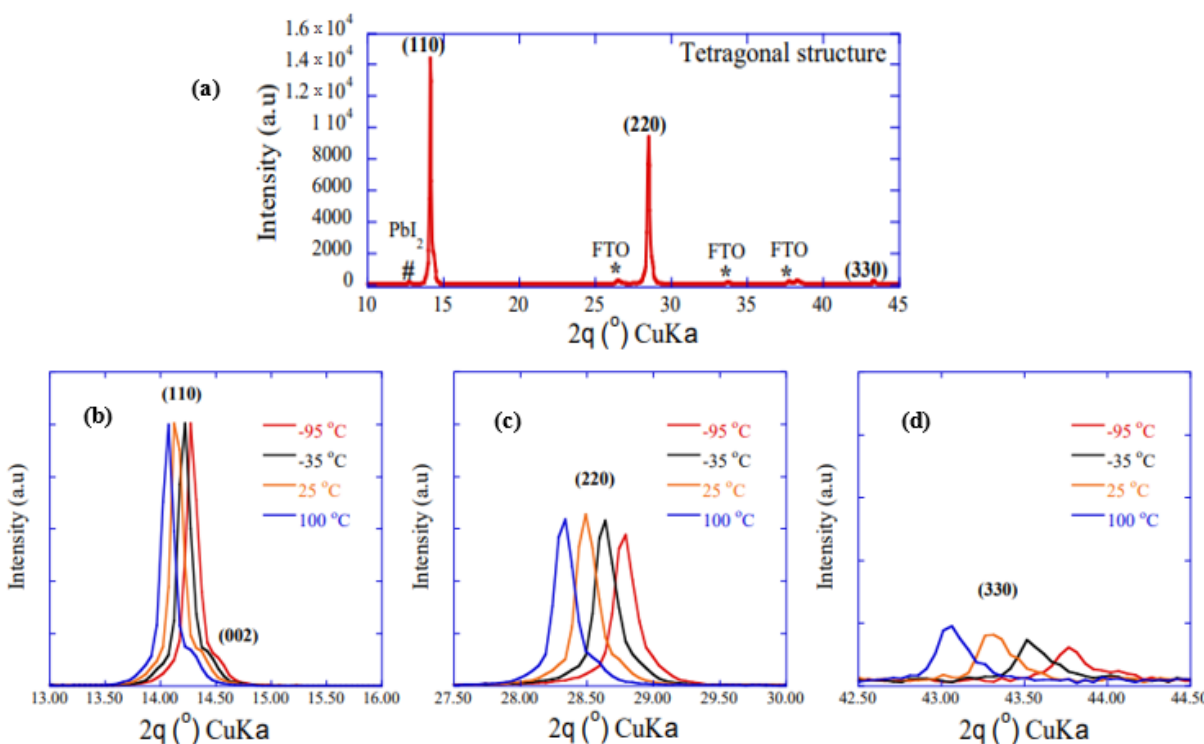

Figure 13. X-ray diffraction pattern of a perovskite sample (a) heated at $25^{\circ} \mathrm{C},(\mathbf{b}-\mathbf{d})$ magnified perovskite $\mathrm{CH}_{3} \mathrm{NH}_{3} \mathrm{PbI}_{3}$ characteristic peaks heating at temperature range $-95^{\circ} \mathrm{C}$ to $100{ }^{\circ} \mathrm{C}$ [78].

(b)
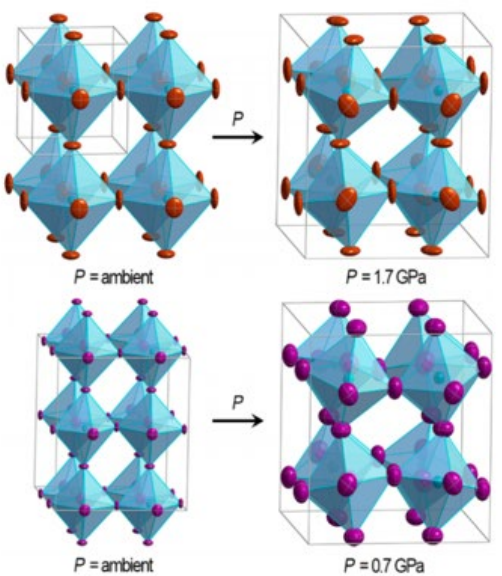

(c)

(d)

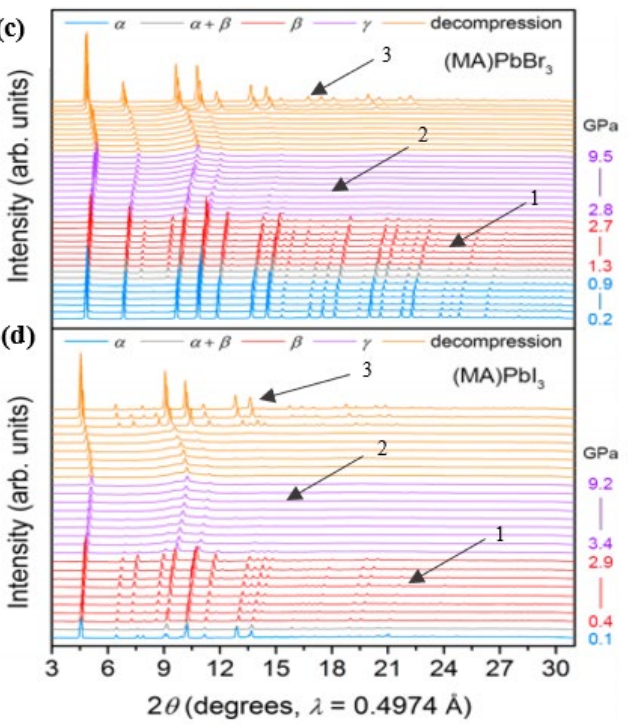

Figure 14. SCXRD schematic representation of crystal structure for (a) $\mathrm{MAPbBr}_{3}$ and (b) $\mathrm{MAPbI}_{3}$ at ambient and high pressures of 1.7 and $0.7 \mathrm{GPa}$, respectively. Changes in PXRD patterns for (c) $\mathrm{MAPbIBr}_{3}$ and (d) $\mathrm{MAPbI}_{3}$ in response to the applied pressure [82]. 


\subsubsection{Environmental Stability}

The perovskite $\mathrm{ABX}_{3}$ materials are chemically active in environmental conditions. A series of chemical reactions occur which slowly break down the $\mathrm{ABX}_{3}$ material into its constituents and additional byproducts. The installation of PSCs exposes the device to environmental contaminants. Oxygen, moisture, and UV radiation constantly wear off the PV perovskite active layer. The chemical reactions below suggest possible perovskite degradation. Moisture breaks down the perovskite layer by dissolving the organic cation $\left(\mathrm{MA}^{+}\right)$to yield $\mathrm{PbI}_{2}$ and $\mathrm{HI}$. This degradation mechanism is an irreversible process as the presence of oxygen and UV radiation further breaks down the hydroiodic acid (HI) producing water $\left(\mathrm{H}_{2} \mathrm{O}\right)$, hydrogen $\left(\mathrm{H}_{2}\right)$ and iodine $\left(\mathrm{I}_{2}\right)$ gases as byproducts (see chemical reactions (2)-(5)) [83]. The chemical reactions (2)-(5) and (6)-(9) are proposed degradation reactions initiated by the presence of UV radiation and moisture. In a study to investigate the degradation of $\mathrm{MAPbI}_{3}$ material exposed to a humid environment, Shirayama (2016) reported a rapid decomposition in the perovskite material at a low relative humidity of $40 \%$ caused by either or both of the following: the formation of $\mathrm{PbI}_{2}$ phase from the desorption of the volatile organic MAI cation, or the formation of a perovskite hydrate phase, resulting from the interaction of $\mathrm{H}_{2} \mathrm{O}$ molecules and the absorber $\mathrm{N}-\mathrm{H}$ bond [84]. In a similar study, Yang (2015) suggested that proper selection of a hydrophobic HTM stabilizes the perovskite layer deterioration; however, the effort only shifts the perovskite lifespan to a few more hours before it begins degrading [85].

$$
\begin{aligned}
\mathrm{CH}_{3} \mathrm{NH}_{3} \mathrm{PbI}_{3}(\mathrm{~s}) & \leftrightarrow \mathrm{PbI}_{2}(\mathrm{~s})+\mathrm{CH}_{3} \mathrm{NH}_{3} \mathrm{I}(\mathrm{aq}) \\
\mathrm{CH}_{3} \mathrm{NH}_{3} \mathrm{I}(\mathrm{aq}) & \leftrightarrow \mathrm{CH}_{3} \mathrm{NH}_{2}(\mathrm{aq})+\mathrm{HI}(\mathrm{aq}) \\
4 \mathrm{HI}(\mathrm{aq})+\mathrm{O}_{2} & \leftrightarrow 2 \mathrm{I}_{2}+2 \mathrm{H}_{2} \mathrm{O}(\mathrm{l}) \\
2 \mathrm{HI}(\mathrm{aq}) & \leftrightarrow \mathrm{H}_{2}(\mathrm{~g})+\mathrm{I}_{2}(\mathrm{~s}) \\
\mathrm{CH}_{3} \mathrm{NH}_{3} \mathrm{PbI}_{3}(\mathrm{~s}) & \leftrightarrow \mathrm{PbI}_{2}(\mathrm{~s})+\mathrm{CH}_{3} \mathrm{NH}_{2} \uparrow+\mathrm{HI} \uparrow \\
2 \mathrm{I}^{-} & \leftrightarrow \mathrm{I}_{2}+2 \mathrm{e}^{-} \\
3 \mathrm{CH}_{3} \mathrm{NH}_{3}{ }^{+} & \leftrightarrow 3 \mathrm{CH}_{3} \mathrm{NH}_{2} \uparrow+3 \mathrm{H}^{+}
\end{aligned}
$$

$\mathrm{I}^{-}+\mathrm{I}_{2}+3 \mathrm{H}^{+}+2 \mathrm{e}^{-} \leftrightarrow 3 \mathrm{HI} \uparrow$. In Figure 15a-c, SEM surface images reveal perovskite film morphology exposed to $40 \%$ relative humidity (RH) at various exposure times. Figure 15a reports a smooth surface at 20 min exposure with a high level of surface coverage; Figure $15 \mathrm{~b}$ reports SEM surface morphology at $24 \mathrm{~h}$ of exposure, showing the formation of evenly distributed holes reducing surface homogeneity (as indicated by arrow 1 ). The generation of holes results from the coalescence of the inorganic $\mathrm{PbI}_{2}$ phase structure as the organic MAI cation dissolves in moisture; Figure 15c demonstrates the SEM image at $48 \mathrm{~h}$ of exposure, showing well-defined rod-like $\mathrm{PbI}_{2}$ structures (as indicated arrow 2) and the extent $\backslash$ of hole formation in the film morphology [85]. Many attempts focus on eliminating the effect of moisture on PSCs by designing new PSC architectures, encapsulating the device using polymers, proposing new ETM and HTM materials, among others, modifying the $\mathrm{ABX}_{3}$ materials.

In order to eliminate the effect of moisture and investigate the effect on UV radiation alone, Lee (2016) studied the degradation of PSCs in an inert atmosphere (glove box) by exposing the PSC devices to UV light. The effect of UV exposure on the device was characterized through XRD and I-V techniques, as shown in Figure 15d,e, respectively. From both characterizations, it is observed that UV degradation is slightly reversible via light soaking the devices (light soaking - exposing to natural sunlight). In Figure 15d, the $\mathrm{XRD}$ patterns show the development of $\mathrm{PbI}_{2}$ peak at $12.6^{\circ}$ diffraction angle accompanied by a fading perovskite characteristic peak at $14.1^{\circ}$ with an increase in UV exposure time. These results are comparable to that of perovskite moisture decomposition. In Figure 15e, the $\mathrm{I}-\mathrm{V}$ curves show that the occurrence of UV degradation decreases the device performance 
after $210 \mathrm{~h}$ of exposure (blue curve). However, light soaking the device works against the degradation process, partially restoring the device's performance.

a

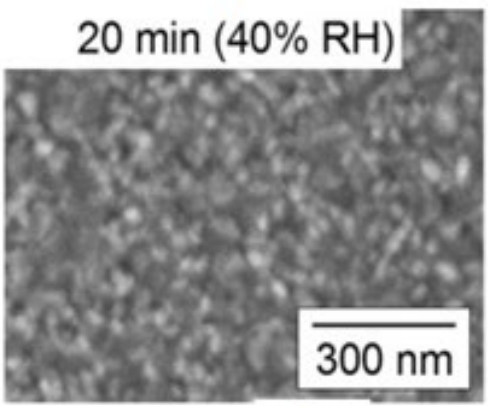

d

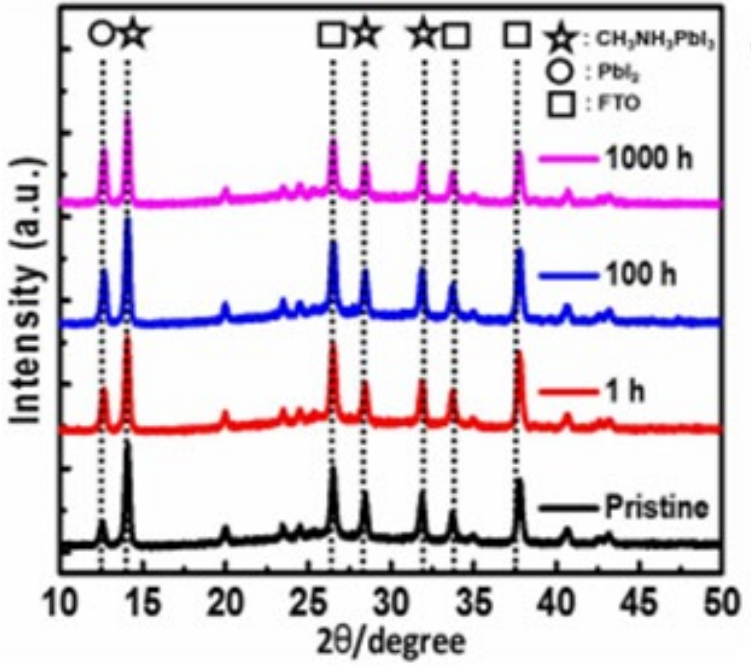

$\mathrm{b}$

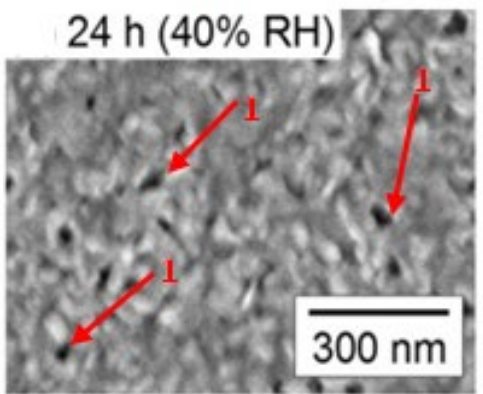

$\mathrm{c}$

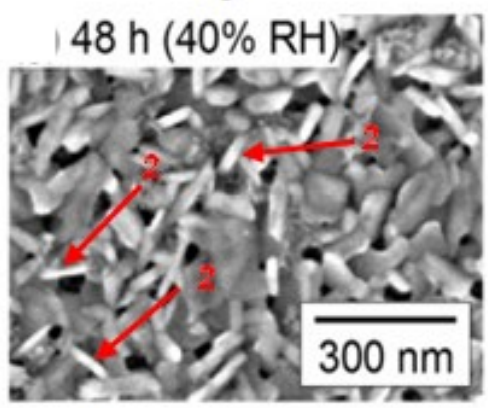

e

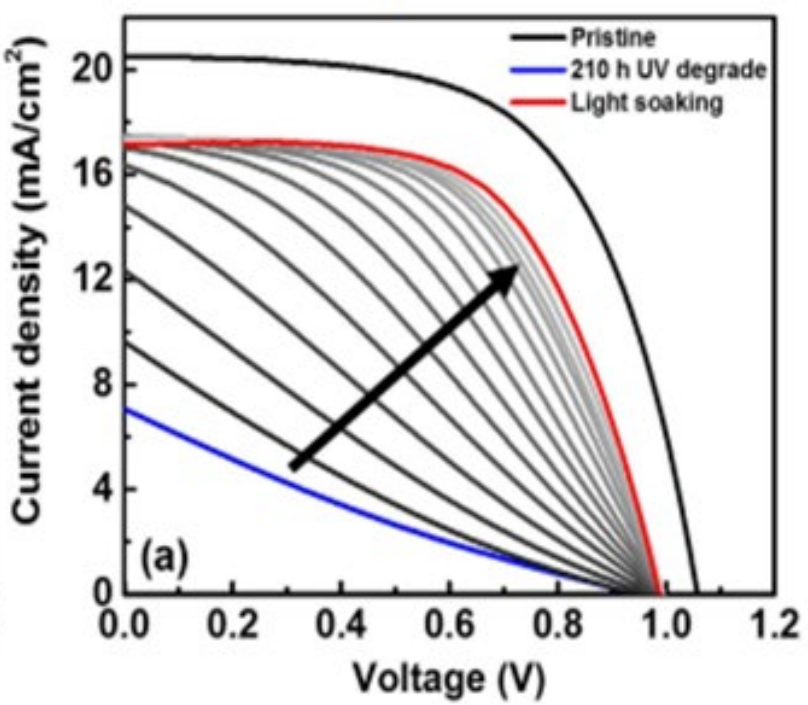

Figure 15. Characterization of perovskite device degradation upon exposure to (a) $40 \%$ relative humidity (RH) and (b-d) $365 \mathrm{~nm}$ UV light. (a) i-iii SEM micrograph images of device exposed for $\mathrm{t}=20 \mathrm{~min}, 24 \mathrm{~h}$ and $48 \mathrm{~h}$ of the $40 \%$ humidity condition. (b) I-V curve, (c) XRD, and (d,e) PCE and FF perovskite response to UV light degradation $[84,86]$.

\section{PSC Encapsulation}

One of the recent effective methods/solutions towards PSC degradation lies in the tight encapsulation of the perovskite material. This method prevents outgassing of the volatile perovskite decomposition products, protecting against moisture and UV radiation. The technology behind encapsulation uses thin-film materials of epoxy, $\mathrm{SnO}_{2}$, butyl rubber, and dyads surrounding the PSC from the top, bottom, and edges [87-90]. In a recent study, Shi (2020) reported a breakthrough in PSC encapsulation surviving extreme standard test conditions specified for commercial modules for about $1800 \mathrm{~h}$ of thermal cycle and 75 humidity freeze test cycles [91]. The PSC devices were encapsulated between transparent conductive oxide substrates and the inexpensive polyisobutylene rubber; a similar approach has been demonstrated in an early study by Kim (2017), as shown in Figure 16 [92]. 


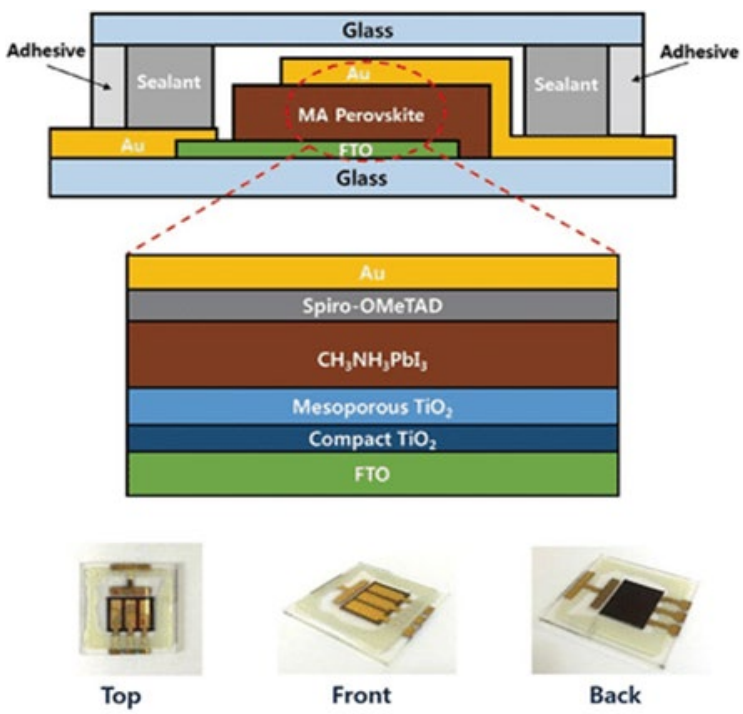

Figure 16. Simplified schematic images of PSC encapsulation, the PSC device architecture, and low-resolution images of the actual PSC device from the top, front, and back [92].

\section{Other Challenges}

\section{Toxicity}

The toxicity in perovskite devices results from the use of the toxic lead (Pd) element. This raises environmental concerns for the upcoming device scaleup for commercialization. The lack of device stability provides a possible way for toxic lead $(\mathrm{Pb})$ leakage from the installed solar panels to the environment [29]. Due to the high demand for energy globally, a rising number of studies encourage the use of $\mathrm{Pb}$-containing devices, as pollution from these devices will be insignificantly small in comparison with other lead-pollution sources around the world [93]. However, there are several promising alternatives for lead replacement with environmentally friendly elements. Noel (2015) worked on replacing the $\mathrm{Pb}$ component and devised a tin $(\mathrm{Sn})$-based perovskite device $\left(\mathrm{MASn}_{3}\right)$ with a promising PCE of $6 \%$. Further studies reported that Sn-based perovskites suffer from instability due to the easy 2+ oxidation of the Sn element in moisture to 4+ states. Hoshi (2016) proposed the use of additives to improve Sn-based devices' stability. This effort showed significant improvement; however, the efficiencies are very low in comparison to Pb-based devices [94,95]. To reinstate the purpose of PSCs, which is high efficiencies and stability, a hybrid $\mathrm{Sn}-\mathrm{Pb}$ perovskite film was proposed and achieved efficiencies of up to 15.2\% [96].

\section{Summary}

A comprehensive review of PSCs was conducted in this study. PSCs are the upcoming cost-effective PV technology, promising to supply sustainable, green, and affordable electricity in the next coming decades. The development in the PSC technology in both industry and academic research is constantly improving. New ideas and milestones are constantly being published. Therefore, this review serves as a guide to interested scientists and new researchers in the field by providing detailed information on PSC device background and stepwise scientific efforts applied to improving the device performance with time. This work reviews previous studies in modelling the perovskite crystal structure and electronic structure, including factors that affect and determine both perovskite intrinsic structures. This study further highlights major developments in perovskite device architecture and fabrication methods towards achieving flexible and high-performance PSC devices. In addition, efforts in the perovskite $\mathrm{ABX}_{3}$ designing and processing condition are elucidated; progress in the perovskite film fabrication is given; good correlation in perovskite film quality or morphology with each fabrication method is clearly explained. Additional efforts in this review have been made to outline recent challenges to PSC commercialization. This 
includes the use of the toxic lead $(\mathrm{Pb})$ element in most $\mathrm{ABX}_{3}$ perovskite compounds and, more importantly, the perovskite material intrinsic and extrinsic instability issues. Among other solutions, the replacement of the toxic lead $(\mathrm{Pb})$ element and encapsulation of the PSCs are highlighted.

\section{Future Research}

Future work will focus on revising and designing new methods to improve PSC performance. We will, in particular, investigate the effect of annealing and doping trivalent and pentavalent dopants on synthesized nanoparticle and nanotube metal oxides, such as titanium and zinc oxide $\left(\mathrm{TiO}_{2}\right.$ and $\left.\mathrm{ZnO}\right)$, for enhanced electron extraction in PSCs. For environmental concerns, further research will focus more on replacing the highly toxic lead $(\mathrm{Pb})$ element with Tin $(\mathrm{Sn})$ due to their similar chemical properties. The widely used hole-transporting material to date is the Spiro-MeOTAD. To fabricate cost-effective devices, cheaper p-type hole-transporting materials, such as $\mathrm{Cu}_{2} \mathrm{O}$ and $\mathrm{NiO}$, will be explored. As a reference or benchmark in our research group, a well-considered fabrication method will be proposed, from which we can build towards the achievement of a fully functional, highly efficient, and stable perovskite device. Aspects to be evaluated in the fabrication method include the effect of precursor concentration, annealing temperatures, annealing time, synthesis period, annealing at various gaseous environments, and exploration of different device architectures.

Author Contributions: Conceptualization, L.P.L., L.F.K., S.V.M., T.E.M. and T.M.; data collection, L.P.L., L.F.K., S.V.M., T.E.M. and T.M.; writing and editing this review, L.P.L., L.F.K., S.V.M., T.E.M. and T.M. All authors have read and agreed to the published version of the manuscript.

Funding: National Research Foundation (NRF) Thuthuka program (Grant No: 121877).

Institutional Review Board Statement: This study does not require ethical clearence.

Informed Consent Statement: This study did not involve any animals or humans.

Data Availability Statement: No data included.

Acknowledgments: The financial assistance of the National Research Foundation (NRF) Thuthuka program (Grant No: 121877) towards this research is hereby acknowledged.

Conflicts of Interest: The authors declare that there is no conflict of interest.

\section{References}

1. Pollet, B.G.; Staffell, I.; Adamson, K.-A. Current energy landscape in the Republic of South Africa. Int. J. Hydrog. Energy 2015, 40, 16685-16701. [CrossRef]

2. Dincer, I. Environmental impacts of energy. Energy Policy 1999, 27, 845-854. [CrossRef]

3. Turner, J.A. A Realizable Renewable Energy Future. Science 1999, 285, 687-689. [CrossRef] [PubMed]

4. Lee, D.G.; Kim, M.-C.; Kim, B.J.; Kim, D.H.; Lee, S.M.; Choi, M.; Lee, S.; Jung, H.S. Effect of $\mathrm{TiO}_{2}$ particle size and layer thickness on mesoscopic perovskite solar cells. Appl. Surf. Sci. 2019, 477, 131-136. [CrossRef]

5. Kojima, A.; Teshima, K.; Shirai, Y.; Miyasaka, T. Organometal Halide Perovskites as Visible-Light Sensitizers for Photovoltaic Cells. J. Am. Chem. Soc. 2009, 131, 6050-6051. [CrossRef] [PubMed]

6. Kim, H.-S.; Im, S.H.; Park, N.-G. Organolead Halide Perovskite: New Horizons in Solar Cell Research. J. Phys. Chem. C 2014, 118, 5615-5625. [CrossRef]

7. Lee, M.M.; Teuscher, J.; Miyasaka, T.; Murakami, T.N.; Snaith, H.J. Efficient Hybrid Solar Cells Based on Meso-Superstructured Organometal Halide Perovskites. Science 2012, 338, 643-647. [CrossRef]

8. Chart of Best Research-Cell Efficiencies Provided by NREL. Available online: http://www.nrel.gov/pv/assets/images/ efficiency_chart.jpg (accessed on 23 December 2021).

9. Meng, L.; You, J.; Guo, T.-F.; Yang, Y. Recent Advances in the Inverted Planar Structure of Perovskite Solar Cells. Acc. Chem. Res. 2015, 49, 155-165. [CrossRef]

10. Abdi-Jalebi, M.; Dar, M.I.; Sadhanala, A.; Senanayak, S.P.; Grätzel, M.; Friend, R.H. Monovalent Cation $\mathrm{Doping}_{\mathrm{O}} \mathrm{CH}_{3} \mathrm{NH}_{3} \mathrm{PbI}_{3}$ for Efficient Perovskite Solar Cells. J. Vis. Exp. 2017, 121, e55307. [CrossRef]

11. Ng, C.; Lim, H.N.; Hayase, S.; Zainal, Z.; Huang, N. Photovoltaic performances of mono- and mixed-halide structures for perovskite solar cell: A review. Renew. Sustain. Energy Rev. 2018, 90, 248-274. [CrossRef] 
12. Liu, Y.; Wang, J. Co-sensitization of $\mathrm{TiO}_{2}$ by PbS quantum dots and dye N719 in dye-sensitized solar cells. Thin Solid Films 2010, 518, e54-e56. [CrossRef]

13. Chen, J.; Zhao, D.; Song, J.-L.; Sun, X.; Deng, W.; Liu, X.; Lei, W. Directly assembled CdSe quantum dots on TiO ${ }_{2}$ in aqueous solution by adjusting $\mathrm{pH}$ value for quantum dot sensitized solar cells. Electrochem. Commun. 2009, 11, 2265-2267. [CrossRef]

14. Zhang, Q.; Zhang, Y.; Huang, S.; Huang, X.; Luo, Y.; Meng, Q.; Li, D. Application of carbon counterelectrode on CdS quantum dot-sensitized solar cells (QDSSCs). Electrochem. Commun. 2010, 12, 327-330. [CrossRef]

15. Im, J.-H.; Lee, C.-R.; Lee, J.-W.; Park, S.-W.; Park, N.-G. 6.5\% efficient perovskite quantum-dot-sensitized solar cell. Nanoscale 2011, 3, 4088-4093. [CrossRef] [PubMed]

16. Fujishima, A.; Zhang, X. Solid-State Dye-Sensitized Solar Cells. Nanostructured Mater. Sol. Energy Convers. 2006, 255-273. [CrossRef]

17. Ball, J.M.; Lee, M.M.; Hey, A.; Snaith, H.J. Low-temperature processed meso-superstructured to thin-film perovskite solar cells Energy Environ. Sci. 2013, 6, 1739-1743. [CrossRef]

18. Zhang, H.; Lv, Y.; Wang, J.; Ma, H.; Sun, Z.; Huang, W. Influence of Cl Incorporation in Perovskite Precursor on the Crystal Growth and Storage Stability of Perovskite Solar Cells. ACS Appl. Mater. Interfaces 2019, 11, 6022-6030. [CrossRef] [PubMed]

19. Jena, A.K.; Kulkarni, A.; Miyasaka, T. Halide Perovskite Photovoltaics: Background, Status, and Future Prospects. Chem. Rev. 2019, 119, 3036-3103. [CrossRef] [PubMed]

20. Docampo, P.; Hanusch, F.C.; Stranks, S.D.; Döblinger, M.; Feckl, J.M.; Ehrensperger, M.; Minar, N.K.; Johnston, M.B.; Snaith, H.J.; Bein, T. Solution Deposition-Conversion for Planar Heterojunction Mixed Halide Perovskite Solar Cells. Adv. Energy Mater. 2014, 4, 1400355. [CrossRef]

21. Ansari, M.I.H.; Qurashi, A.; Nazeeruddin, M.K. Frontiers, opportunities, and challenges in perovskite solar cells: A critical review. J. Photochem. Photobiol. C Photochem. Rev. 2018, 35, 1-24. [CrossRef]

22. Grånäs, O.; Vinichenko, D.; Kaxiras, E. Establishing the limits of efficiency of perovskite solar cells from first principles modeling. Sci. Rep. 2016, 6, 36108. [CrossRef] [PubMed]

23. Correa-Baena, J.-P.; Abate, A.; Saliba, M.; Tress, W.; Jacobsson, T.J.; Grätzel, M.; Hagfeldt, A. The rapid evolution of highly efficient perovskite solar cells. Energy Environ. Sci. 2017, 10, 710-727. [CrossRef]

24. Kayes, B.M.; Nie, H.; Twist, R.; Spruytte, S.G.; Reinhardt, F.; Kizilyalli, I.C.; Higashi, G.S. 27.6\% Conversion efficiency, a new record for single-junction solar cells under 1 sun illumination. In Proceedings of the Conference Record of the IEEE Photovoltaic Specialists Conference, Seattle, WA, USA, 19-24 June 2011. [CrossRef]

25. Roghabadi, F.A.; Alidaei, M.; Mousavi, S.M.; Ashjari, T.; Tehrani, A.S.; Ahmadi, V.; Sadrameli, S.M. Stability progress of perovskite solar cells dependent on the crystalline structure: From 3D ABX3 to 2D Ruddlesden-Popper perovskite absorbers. J. Mater. Chem. A 2019, 7, 5898-5933. [CrossRef]

26. Shi, Z.; Jayatissa, A.H. Perovskites-Based Solar Cells: A Review of Recent Progress, Materials and Processing Methods. Materials 2018, 11, 729. [CrossRef]

27. Li, B.; Li, Y.; Zheng, C.; Gao, D.; Huang, W. Advancements in the stability of perovskite solar cells: Degradation mechanisms and improvement approaches. RSC Adv. 2016, 6, 38079-38091. [CrossRef]

28. Adhyaksa, G.W.P.; Veldhuizen, L.W.; Kuang, Y.; Brittman, S.; Schropp, R.E.I.; Garnett, E.C. Carrier Diffusion Lengths in Hybrid Perovskites: Processing, Composition, Aging, and Surface Passivation Effects. Chem. Mater. 2016, 28, 5259-5263. [CrossRef]

29. Chen, Y.; Zhang, L.; Zhang, Y.; Gao, H.; Yan, H. Large-area perovskite solar cells-A review of recent progress and issues. RSC Adv. 2018, 8, 10489-10508. [CrossRef]

30. Hamed, M.S.G.; Mola, G.T. Mixed Halide Perovskite Solar Cells: Progress and Challenges. Crit. Rev. Solid State Mater. Sci. 2020, 45, 85-112. [CrossRef]

31. Shen, K.; Hu, J.; Liang, Z.; Hu, J.; Sun, H.; Jiang, Z.; Song, F. Emerging Characterizing Techniques in the Fine Structure Observation of Metal Halide Perovskite Crystal. Crystals 2018, 8, 232. [CrossRef]

32. Forrester, W.F.; Hinde, R.M. Crystal Structure of Barium Titanate. Nature 1945, 156, 177. [CrossRef]

33. Chen, J.; Cai, X.; Yang, D.; Song, D.; Wang, J.; Jiang, J.; Ma, A.; Lv, S.; Hu, M.Z.; Ni, C. Recent progress in stabilizing hybrid perovskites for solar cell applications. J. Power Sources 2017, 355, 98-133. [CrossRef]

34. Korshunova, K.; Winterfeld, L.; Beenken, W.J.D.; Runge, E. Thermodynamic stability of mixed Pb:Sn methyl-ammonium halide perovskites. Phys. Status Solidi B Basic Res. 2016, 253, 1907-1915. [CrossRef]

35. Yin, W.-J.; Shi, T.; Yan, Y. Unusual defect physics in CH3NH3PbI3 perovskite solar cell absorber. Appl. Phys. Lett. 2014, 104, 063903. [CrossRef]

36. Zhou, Y.; Huang, F.; Cheng, Y.-B.; Gray-Weale, A. Photovoltaic performance and the energy landscape of $\mathrm{CH}_{3} \mathrm{NH}_{3} \mathrm{PbI}_{3} . \mathrm{Phys}$ Chem. Chem. Phys. 2015, 17, 22604-22615. [CrossRef]

37. Kim, H.-S.; Lee, C.-R.; Im, J.-H.; Lee, K.-B.; Moehl, T.; Marchioro, A.; Moon, S.-J.; Humphry-Baker, R.; Yum, J.-H.; Moser, J.E.; et al. Lead Iodide Perovskite Sensitized All-Solid-State Submicron Thin Film Mesoscopic Solar Cell with Efficiency Exceeding 9\%. Sci. Rep. 2012, 2, 591. [CrossRef]

38. Chibueze, T.C. Comparative study of the structural and electronic properties of orthorhombic $\mathrm{CH}_{3} \mathrm{NH}_{3} \mathrm{PbI}_{3}$ hybrid perovskite for solar cell applications. Niger. J. Technol. 2021, 40, 616-622. [CrossRef]

39. Zhang, J.; Zhang, L.; Li, X.; Zhu, X.; Yu, J.; Fan, K. Binary Solvent Engineering for High-Performance Two-Dimensional Perovskite Solar Cells. ACS Sustain. Chem. Eng. 2019, 7, 3487-3495. [CrossRef] 
40. Song, Z.; Watthage, S.C.; Phillips, A.B.; Heben, M.J. Pathways toward high-performance perovskite solar cells: Review of recent advances in organo-metal halide perovskites for photovoltaic applications. J. Photon. Energy 2016, 6, 22001. [CrossRef]

41. Eperon, G.E.; Burlakov, V.M.; Docampo, P.; Goriely, A.; Snaith, H.J. Morphological Control for High Performance, SolutionProcessed Planar Heterojunction Perovskite Solar Cells. Adv. Funct. Mater. 2014, 24, 151-157. [CrossRef]

42. Yang, S.; Han, Q.; Wang, L.; Zhou, Y.; Yu, F.; Li, C.; Cai, X.; Gao, L.; Zhang, C.; Ma, T. Over 23\% power conversion efficiency of planar perovskite solar cells via bulk heterojunction design. Chem. Eng. J. 2021, 426, 131838. [CrossRef]

43. Heo, J.H.; Lee, M.H.; Jang, M.H.; Im, S.H. Highly efficient CH3NH3PbI3-xClx mixed halide perovskite solar cells prepared by re-dissolution and crystal grain growth via spray coating. J. Mater. Chem. A 2016, 4, 17636-17642. [CrossRef]

44. Matsui, T.; Seo, J.-Y.; Saliba, M.; Zakeeruddin, S.M.; Grätzel, M. Room-Temperature Formation of Highly Crystalline Multication Perovskites for Efficient, Low-Cost Solar Cells. Adv. Mater. 2017, 29, 1606258. [CrossRef] [PubMed]

45. Wang, H.; Yu, Z.; Jiang, X.; Li, J.; Cai, B.; Yang, X.; Sun, L. Efficient and Stable Inverted Planar Perovskite Solar Cells Employing $\mathrm{CuI}$ as Hole-Transporting Layer Prepared by Solid-Gas Transformation. Energy Technol. 2017, 5, 1836-1843. [CrossRef]

46. Ren, J.; Qu, J.; Chen, J.; Li, Z.; Cui, Y.; Wang, H.; Yu, Z.; Hao, Y. Fluorinated dopant-free hole-transporting material for efficient and stable perovskite solar cells with carbon cathode. J. Power Sources 2018, 401, 29-36. [CrossRef]

47. Suarez, B.; Gonzalez-Pedro, V.; Ripolles, T.S.; Sanchez, R.S.; Otero, L.; Mora-Sero, I. Recombination Study of Combined Halides (Cl, Br, I) Perovskite Solar Cells. J. Phys. Chem. Lett. 2014, 5, 1628-1635. [CrossRef] [PubMed]

48. Singh, T.; Miyasaka, T. Stabilizing the Efficiency Beyond 20\% with a Mixed Cation Perovskite Solar Cell Fabricated in Ambient Air under Controlled Humidity. Adv. Energy Mater. 2018, 8, 1700677. [CrossRef]

49. Saliba, M.; Matsui, T.; Domanski, K.; Seo, J.-Y.; Ummadisingu, A.; Zakeeruddin, S.M.; Correa-Baena, J.-P.; Tress, W.R.; Abate, A.; Hagfeldt, A.; et al. Incorporation of rubidium cations into perovskite solar cells improves photovoltaic performance. Science 2016, 354, 206-209. [CrossRef] [PubMed]

50. Kim, B.J.; Kim, D.H.; Lee, Y.-Y.; Shin, H.-W.; Han, G.S.; Hong, J.S.; Mahmood, K.; Ahn, T.K.; Joo, Y.-C.; Hong, K.S.; et al. Highly efficient and bending durable perovskite solar cells: Toward a wearable power source. Energy Environ. Sci. 2015, 8, 916-921. [CrossRef]

51. Tavakoli, M.M.; Lin, Q.; Leung, S.-F.; Lui, G.C.; Lu, H.; Li, L.; Xiang, B.; Fan, Z. Efficient, flexible and mechanically robust perovskite solar cells on inverted nanocone plastic substrates. Nanoscale 2016, 8, 4276-4283. [CrossRef]

52. Yang, B.; Peng, S.; Choy, W.C.H. Inorganic top electron transport layer for high performance inverted perovskite solar cells. EcoMat 2021, 3, e12127. [CrossRef]

53. Barrows, A.T.; Pearson, A.J.; Kwak, C.K.; Dunbar, A.D.F.; Buckley, A.R.; Lidzey, D.G. Efficient planar heterojunction mixed-halide perovskite solar cells deposited via spray-deposition. Energy Environ. Sci. 2014, 7, 2944-2950. [CrossRef]

54. Saliba, M.; Correa-Baena, J.-P.; Wolff, C.M.; Stolterfoht, M.; Phung, N.; Albrecht, S.; Neher, D.; Abate, A. How to Make over 20\% Efficient Perovskite Solar Cells in Regular ( $n-i-p)$ and Inverted (p-i-n) Architectures. Chem. Mater. 2018, 30, $4193-4201$. [CrossRef]

55. Dubey, A.; Adhikari, N.; Mabrouk, S.; Wu, F.; Chen, K.; Yang, S.; Qiao, Q. A strategic review on processing routes towards highly efficient perovskite solar cells. J. Mater. Chem. A 2018, 6, 2406-2431. [CrossRef]

56. Xu, F.; Zhang, T.; Li, G.; Zhao, Y. Mixed cation hybrid lead halide perovskites with enhanced performance and stability. J. Mater. Chem. A 2017, 5, 11450-11461. [CrossRef]

57. Saliba, M.; Matsui, T.; Seo, J.-Y.; Domanski, K.; Correa-Baena, J.-P.; Nazeeruddin, M.K.; Zakeeruddin, S.M.; Tress, W.; Abate, A.; Hagfeldt, A.; et al. Cesium-containing triple cation perovskite solar cells: Improved stability, reproducibility and high efficiency. Energy Environ. Sci. 2016, 9, 1989-1997. [CrossRef]

58. Malevu, T.D.; Mwankemwa, B.S.; Tshabalala, K.G.; Diale, M.; Ocaya, R.O. Effect of 6R and 12R lead iodide polytypes on MAPbI3 perovskite device performance. J. Mater. Sci. Mater. Electron. 2018, 29, 13011-13018. [CrossRef]

59. Nagarjuna, P.; Narayanaswamy, K.; Swetha, T.; Rao, G.H.; Singh, S.P.; Sharma, G. CH3NH3PbI3 Perovskite Sensitized Solar Cells Using a D-A Copolymer as Hole Transport Material. Electrochimica Acta 2015, 151, 21-26. [CrossRef]

60. Tong, X.; Lin, F.; Wu, J.; Wang, Z.M. High Performance Perovskite Solar Cells. Adv. Sci. 2016, 3, 1500201. [CrossRef]

61. Elumalai, N.K.; Mahmud, A.; Wang, D.; Uddin, A. Perovskite Solar Cells: Progress and Advancements. Energies 2016, 9 , 861. [CrossRef]

62. Chen, L.-C.; Chen, J.-C.; Chen, C.-C.; Wu, C.-G. Fabrication and Properties of High-Efficiency Perovskite/PCBM Organic Solar Cells. Nanoscale Res. Lett. 2015, 10, 312. [CrossRef]

63. Filho, J.M.C.D.S.; Ermakov, V.A.; Marques, F.C. Perovskite Thin Film Synthesised from Sputtered Lead Sulphide. Sci. Rep. 2018, 8, 1563. [CrossRef]

64. Torabi, N.; Behjat, A.; Zhou, Y.; Docampo, P.; Stoddard, R.J.; Hillhouse, H.W.; Ameri, T. Progress and challenges in perovskite photovoltaics from single- to multi-junction cells. Mater. Today Energy 2019, 12, 70-94. [CrossRef]

65. Burschka, J.; Pellet, N.; Moon, S.-J.; Humphry-Baker, R.; Gao, P.; Nazeeruddin, M.K.; Grätzel, M. Sequential deposition as a route to high-performance perovskite-sensitized solar cells. Nature 2013, 499, 316-319. [CrossRef]

66. Zhao, Q.; Wu, R.; Zhang, Z.; Xiong, J.; He, Z.; Fan, B.; Dai, Z.; Yang, B.; Xue, X.; Cai, P.; et al. Achieving efficient inverted planar perovskite solar cells with nondoped PTAA as a hole transport layer. Org. Electron. 2019, 71, 106-112. [CrossRef] 
67. Zhou, Y.; Yang, M.; Vasiliev, A.L.; Garces, H.F.; Zhao, Y.; Wang, D.; Pang, S.; Zhu, K.; Padture, N.P. Growth control of compact $\mathrm{CH} 3 \mathrm{NH} 3 \mathrm{PbI} 3$ thin films via enhanced solid-state precursor reaction for efficient planar perovskite solar cells. J. Mater. Chem. A 2015, 3, 9249-9256. [CrossRef]

68. Li, W.; Fan, J.; Li, J.; Mai, Y.; Wang, L. Controllable Grain Morphology of Perovskite Absorber Film by Molecular Self-Assembly toward Efficient Solar Cell Exceeding 17\%. J. Am. Chem. Soc. 2015, 137, 10399-10405. [CrossRef]

69. Wang, Q.; Shao, Y.; Xie, H.; Lyu, L.; Liu, X.; Gao, Y.; Huang, J. Qualifying composition dependent $\mathrm{p}$ and $\mathrm{n}$ self-doping in CH3NH3PbI3. Appl. Phys. Lett. 2014, 105, 163508. [CrossRef]

70. Tafazoli, S.; Timasi, N.; Nouri, E.; Mohammadi, M.R. The role of a vapor-assisted solution process on tailoring the chemical composition and morphology of mixed-halide perovskite solar cells. CrystEngComm 2018, 20, 4428-4435. [CrossRef]

71. Zimmermann, I.; Al Atem, M.; Fournier, O.; Bernard, S.; Jutteau, S.; Lombez, L.; Rousset, J. Sequentially Slot-Die-Coated Perovskite for Efficient and Scalable Solar Cells. Adv. Mater. Interfaces 2021, 8, 2100743. [CrossRef]

72. Khadka, D.B.; Shirai, Y.; Yanagida, M.; Masuda, T.; Miyano, K. Enhancement in efficiency and optoelectronic quality of perovskite thin films annealed in MACl vapor. Sustain. Energy Fuels 2017, 1, 755-766. [CrossRef]

73. Chen, J.; Xu, J.; Xiao, L.; Zhang, B.; Dai, S.; Yao, J. Mixed-Organic-Cation (FA)x(MA)1-xPbI3 Planar Perovskite Solar Cells with 16.48\% Efficiency via a Low-Pressure Vapor-Assisted Solution Process. ACS Appl. Mater. Interfaces 2017, 9, 2449-2458. [CrossRef] [PubMed]

74. Liu, M.; Johnston, M.; Snaith, H. Efficient planar heterojunction perovskite solar cells by vapour deposition. Nature 2013, 501, 395-398. [CrossRef] [PubMed]

75. Liang, G.; Lan, H.; Fan, P.; Lan, C.; Zheng, Z.; Peng, H.; Luo, J. Highly Uniform Large-Area $\left(100 \mathrm{~cm}^{2}\right)$ Perovskite CH3NH3PbI3 Thin-Films Prepared by Single-Source Thermal Evaporation. Coatings 2018, 8, 256. [CrossRef]

76. Berhe, T.A.; Su, W.-N.; Chen, C.-H.; Pan, C.-J.; Cheng, J.-H.; Chen, H.-M.; Tsai, M.-C.; Chen, L.-Y.; Dubale, A.A.; Hwang, B.-J. Organometal halide perovskite solar cells: Degradation and stability. Energy Environ. Sci. 2016, 9, 323-356. [CrossRef]

77. Han, G.; Hadi, H.D.; Bruno, A.; Kulkarni, S.A.; Koh, T.M.; Wong, L.H.; Soci, C.; Mathews, N.; Zhang, S.; Mhaisalkar, S.G. Additive Selection Strategy for High Performance Perovskite Photovoltaics. J. Phys. Chem. C 2018, 122, 13884-13893. [CrossRef]

78. Cojocaru, L.; Uchida, S.; Sanehira, Y.; Gonzalez-Pedro, V.; Bisquert, J.; Nakazaki, J.; Kubo, T.; Segawa, H. Temperature Effects on the Photovoltaic Performance of Planar Structure Perovskite Solar Cells. Chem. Lett. 2015, 44, 1557-1559. [CrossRef]

79. Bach, U.; Lupo, D.; Comte, P.; Moser, J.-E.; Weissörtel, F.; Salbeck, J.; Spreitzer, H.; Gratzel, M. Solid-state dye-sensitized mesoporous $\mathrm{TiO} 2$ solar cells with high photon-to-electron conversion efficiencies. Nature 1998, 395, 583-585. [CrossRef]

80. Jiang, S.; Fang, Y.; Li, R.; Xiao, H.; Crowley, J.; Wang, C.; White, T.J.; Iii, W.A.G.; Wang, Z.; Baikie, T.; et al. Pressure-Dependent Polymorphism and Band-Gap Tuning of Methylammonium Lead Iodide Perovskite. Angew. Chem. Int. Ed. 2016, 55, 6540-6544. [CrossRef]

81. Errandonea, D.; Santamaria-Perez, D.; Martinez-Garcia, D.; Gomis, O.; Shukla, R.; Achary, S.N.; Tyagi, A.K.; Popescu, C. Pressure Impact on the Stability and Distortion of the Crystal Structure of $\mathrm{CeScO}_{3}$. Inorg. Chem. 2017, 56, 8363-8371. [CrossRef]

82. Jaffe, A.; Lin, Y.; Beavers, C.; Voss, J.; Mao, W.L.; Karunadasa, H.I. High-Pressure Single-Crystal Structures of 3D Lead-Halide Hybrid Perovskites and Pressure Effects on their Electronic and Optical Properties. ACS Central Sci. 2016, 2, 201-209. [CrossRef]

83. Wu, T.; Qin, Z.; Wang, Y.; Wu, Y.; Chen, W.; Zhang, S.; Cai, M.; Dai, S.; Zhang, J.; Liu, J.; et al. The Main Progress of Perovskite Solar Cells in 2020-2021. Nano-Micro Lett. 2021, 13, 152. [CrossRef] [PubMed]

84. Shirayama, M.; Kato, M.; Miyadera, T.; Sugita, T.; Fujiseki, T.; Hara, S.; Kadowaki, H.; Murata, D.; Chikamatsu, M.; Fujiwara, H. Degradation mechanism of CH3NH3PbI3 perovskite materials upon exposure to humid air. J. Appl. Phys. 2016, $119,115501$. [CrossRef]

85. Yang, J.; Siempelkamp, B.D.; Liu, D.; Kelly, T.L. Investigation of $\mathrm{CH}_{3} \mathrm{NH}_{3} \mathrm{PbI}_{3}$ Degradation Rates and Mechanisms in Controlled Humidity Environments Using in Situ Techniques. ACS Nano 2015, 9, 1955-1963. [CrossRef] [PubMed]

86. Lee, S.-W.; Kim, S.; Bae, S.; Cho, K.; Chung, T.; Mundt, L.E.; Lee, S.; Park, S.; Park, H.; Schubert, M.C.; et al. UV Degradation and Recovery of Perovskite Solar Cells. Sci. Rep. 2016, 6, 38150. [CrossRef] [PubMed]

87. Ramasamy, E.; Karthikeyan, V.; Rameshkumar, K.; Veerappan, G. Glass-to-glass encapsulation with ultraviolet light curable epoxy edge sealing for stable perovskite solar cells. Mater. Lett. 2019, 250, 51-54. [CrossRef]

88. Boyd, C.C.; Cheacharoen, R.; Bush, K.A.; Prasanna, R.; Leijtens, T.; McGehee, M.D. Barrier Design to Prevent Metal-Induced Degradation and Improve Thermal Stability in Perovskite Solar Cells. ACS Energy Lett. 2018, 3, 1772-1778. [CrossRef]

89. Shi, L.; Young, T.L.; Kim, J.; Sheng, Y.; Wang, L.; Chen, Y.; Feng, Z.; Keevers, M.J.; Hao, X.; Verlinden, P.; et al. Accelerated Lifetime Testing of Organic-Inorganic Perovskite Solar Cells Encapsulated by Polyisobutylene. ACS Appl. Mater. Interfaces 2017, 9 , 25073-25081. [CrossRef]

90. Lee, Y.I.; Jeon, N.J.; Kim, B.J.; Shim, H.; Yang, T.-Y.; Seok, S.I.; Seo, J.; Im, S.G. A Low-Temperature Thin-Film Encapsulation for Enhanced Stability of a Highly Efficient Perovskite Solar Cell. Adv. Energy Mater. 2018, 8, 1701928. [CrossRef]

91. Shi, L.; Bucknall, M.P.; Young, T.L.; Zhang, M.; Hu, L.; Bing, J.; Lee, D.S.; Kim, J.; Wu, T.; Takamure, N.; et al. Gas chromatographymass spectrometry analyses of encapsulated stable perovskite solar cells. Science 2020, 368, eaba2412. [CrossRef]

92. Kim, N.-K.; Min, Y.H.; Noh, S.; Cho, E.; Jeong, G.; Joo, M.; Ahn, S.-W.; Lee, J.S.; Kim, S.; Ihm, K.; et al. Investigation of Thermally Induced Degradation in CH3NH3PbI3 Perovskite Solar Cells using In-situ Synchrotron Radiation Analysis. Sci. Rep. 2017, 7, 4645. [CrossRef] 
93. Jiya, J.Y.; Enaburekhan, J.S.; Jimoh, M.T.; Egwim, E.C. A Fundamental Review of Trends in Perovskite Solar Cells Based on Introduction of Buffer Layers to Enhance Stability. ATBU J. Sci. Technol. Educ. 2020, 8, 275-283.

94. Noel, N.K.; Stranks, S.D.; Abate, A.; Wehrenfennig, C.; Guarnera, S.; Haghighirad, A.-A.; Sadhanala, A.; Eperon, G.E.; Pathak, S.K.; Johnston, M.B.; et al. Lead-free organic-inorganic tin halide perovskites for photovoltaic applications. Energy Environ. Sci. 2014, 7, 3061-3068. [CrossRef]

95. Hoshi, H.; Shigeeda, N.; Dai, T. Improved oxidation stability of tin iodide cubic perovskite treated by 5-ammonium valeric acid iodide. Mater. Lett. 2016, 183, 391-393. [CrossRef]

96. Zhu, H.L.; Xiao, J.; Mao, J.; Zhang, H.; Zhao, Y.; Choy, W.C.H. Controllable Crystallization of $\mathrm{CH}_{3} \mathrm{NH}_{3} \mathrm{Sn}_{0.25} \mathrm{~Pb}_{0.75} \mathrm{I}_{3} \mathrm{Perovskites}$ for Hysteresis-Free Solar Cells with Efficiency Reaching 15.2\%. Adv. Funct. Mater. 2017, 27, 1605469. [CrossRef] 